\title{
The effects of forage proportion and rapidly degradable dry matter from concentrate on ruminal digestion in dairy cows fed corn silage-based diets with fixed neutral detergent fiber and starch contents
}

\author{
C. Lechartier and J.-L. Peyraud ${ }^{1}$ \\ INRA, UMR1080 Production du lait, F-35590, St-Gilles, France and Agrocampus Ouest, UMR1080 Production du lait, F-35000, Rennes, France
}

\begin{abstract}
This study investigated the effects of the forage-toconcentrate $(\mathrm{F}: \mathrm{C})$ ratio and the rate of ruminal degradation of carbohydrates from the concentrate on digestion in dairy cows fed corn silage-based diets. Six cows with ruminal cannulas were assigned to 6 treatments in a 6 $\times 6$ Latin square. Treatments were arranged in a $3 \times 2$ factorial design. Three proportions of neutral detergent fiber from forage [FNDF; 7.6, 13.2, and $18.9 \%$ of dry matter (DM)] were obtained by modifying F:C (20:80, 35:65, and 50:50). These F:C were combined with concentrates with either high or low content of rapidly degradable carbohydrates. The dietary content of rapidly degradable carbohydrates from the concentrate was estimated from the DM disappearance of concentrate after $4 \mathrm{~h}$ of in sacco incubation (CRDM). Thus, 2 proportions of CRDM were tested (20 and $30 \%$ of DM). Wheat and corn grain were used as rapidly and slowly degradable starch sources, respectively. Soybean hulls and citrus pulp were used as slowly and rapidly degradable fiber sources, respectively. Concentrate composition was adjusted to maintain dietary starch and neutral detergent fiber contents at 35.9 and $28.9 \%$ of DM, respectively. There was no effect of the interaction between F:C and CRDM on DM intake (DMI), ruminal fermentation, chewing activity, and fibrolytic activity. When F:C decreased, DMI increased, the mean ruminal $\mathrm{pH}$ linearly decreased, and the $\mathrm{pH}$ range linearly increased from 0.95 to $1.27 \mathrm{pH}$ unit. At the same time, the acetateto-propionate ratio decreased linearly. Decreasing F:C linearly decreased the average time spent chewing per kilogram of DMI from 35.2 to $19.5 \mathrm{~min} / \mathrm{kg}$ of DMI and decreased ruminal liquid outflow from 11.6 to 9.2 $\mathrm{L} / \mathrm{kg}$ of DMI, suggesting a decrease in the salivary flow. Increasing CRDM decreased DMI and increased the time during which $\mathrm{pH}$ was below 6.0 (3.1 vs. $4.8 \mathrm{~h}$ ), the $\mathrm{pH}$ range $(0.90$ vs. 1.33$)$, and the initial rate of $\mathrm{pH}$
\end{abstract}

Received May 4, 2009.

Accepted September 29, 2009.

${ }^{1}$ Corresponding author: jean-louis.peyraud@rennes.inra.fr drop. It also increased the volatile fatty acid range (35 vs. $59 \mathrm{mM}$ ), thus suggesting an increased rate of fermentation. It also decreased the acetate-to-propionate ratio (2.9 vs. 1.8). Increasing CRDM barely affected the average time spent chewing per kilogram of DMI and the ruminal liquid outflow. These results suggest that rumen $\mathrm{pH}$ is controlled by different mechanisms when $\mathrm{F}: \mathrm{C}$ is decreased or when CRDM is increased. Consequently, FNDF is a good predictor of the chewing time, whereas CRDM is a good predictor of the $\mathrm{pH}$ range and volatile fatty acid profiles. Finally, considering both FNDF and CRDM improves the prediction of mean $\mathrm{pH}$.

Key words: physically effective fiber, rate of degradation, rumen $\mathrm{pH}$, dairy cow

\section{INTRODUCTION}

The increase of the genetic potential of dairy cows for milk production during recent years has led to the use of high-starch diets to maximize milk production (Plaizier et al., 2008). Conversely, these diets can lead to subacute ruminal acidosis (SARA). A low ruminal $\mathrm{pH}$ leads to a decrease in digestive effectiveness, which, in turn, leads to a decrease in DMI, milk yield, milk fat content, fiber digestibility, and many other disorders (Plaizier et al., 2008). Subacute ruminal acidosis is defined as periods of moderately depressed ruminal pH (Beauchemin et al., 2003; Rustomo et al., 2006a; Yang and Beauchemin, 2009). Although there is no clear agreement on thresholds for abnormal ruminal $\mathrm{pH}$ indicating SARA, a pH depression below 5.6 to 5.8 is generally accepted as an indicator (Beauchemin et al., 2003).

The intake of coarse dietary particles has long been recognized as promoting healthy rumen function by stimulating chewing and saliva production, which helps maintain ruminal buffering capacity (Mertens, 1997). Because reducing the forage particle size also reduces the time spent chewing (Grant et al., 1990), the concept of physically effective NDF (peNDF) proposed by Mertens (1997), which combines measures of chemical 
(i.e., NDF concentration) and physical characteristics of fiber (i.e., particle size), more accurately predicts the response of ruminal $\mathrm{pH}$ compared with total dietary NDF (Zebeli et al., 2008). However, in corn silage-based TMR, the size of particles of forage does not affect ruminal $\mathrm{pH}$, and NDF from forage (FNDF) appears to be the main governing factor of chewing time (Tafaj et al., 2007).

Feeding more concentrate also decreases ruminal $\mathrm{pH}$ because grains are generally more rumen digestible than forages. Zebeli et al. (2008) proposed predicting ruminal $\mathrm{pH}$ by considering simultaneously the dietary contents of peNDF and ruminally degraded starch from grains. This latter criterion is estimated from in sacco incubation of feedstuffs, the data being tabulated (INRA-AFZ, 2004). Fibrous feedstuffs may also contribute to a drop in ruminal $\mathrm{pH}$. In vitro measurements have even shown that dehydrated sugar beet pulp leads to a greater $\mathrm{pH}$ decrease than barley (De Smet et al., 1995; Rustomo et al., 2006b) because of its high content of sugar and pectin, which are rapidly fermented carbohydrates. Because starch or fiber-rich feedstuffs encompass a heterogeneous group of components, the effect of carbohydrate sources on ruminal $\mathrm{pH}$ cannot be predicted solely from their chemical composition. Some studies have suggested that the effect of carbohydrate sources on ruminal $\mathrm{pH}$ can be predicted well from the DM disappearing in $3 \mathrm{~h}$ (De Smet et al., 1995) or $4 \mathrm{~h}$ (Peyraud, 2000) of in sacco incubation.

Decreasing the forage-to-concentrate $(\mathbf{F}: \mathbf{C})$ ratio in the diet is often associated with a decrease in ruminal $\mathrm{pH}$ (Yang and Beauchemin, 2007; Yang and Beauchemin, 2009). However, in these studies, the effects of decreasing FNDF by decreasing F:C were associated with an increased amount of dietary rapidly degradable carbohydrates from concentrate and changes in the dietary starch-to-fiber ratio. The objective of this study was to examine the effect on ruminal digestion of FNDF and the dietary content of rapidly degradable carbohydrates from the concentrate and the interaction between the 2 factors in dairy cows fed TMR with similar NDF and starch contents.

\section{MATERIALS AND METHODS}

\section{Animals and Experimental Design}

The trial was conducted as a $6 \times 6$ Latin square design with a $3 \times 2$ factorial arrangement of treatments with 6 ruminally cannulated lactating Holstein cows (means \pm SD: $653 \pm 34 \mathrm{~kg}$ of BW; $117 \pm 36$ DIM; $39.4 \pm 8.1 \mathrm{~kg} / \mathrm{d}$ of milk yield; $37.9 \pm 6.8 \mathrm{~g} / \mathrm{kg}$ of milk fat content; $30.3 \pm 0.9 \mathrm{~g} / \mathrm{kg}$ of milk protein content). The protein and fat contents were measured before the beginning of the experiment when the cows were fed a corn silage-based diet with $35 \%$ concentrate. The trial included a 2-wk preexperimental adaptation period to monitor DM voluntarily ingested. Each experimental period was $14 \mathrm{~d}$ in duration, with $9 \mathrm{~d}$ of treatment adaptation and $5 \mathrm{~d}$ of data collection.

The ruminal cannulas measured $123 \mathrm{~mm}$ in diameter. Procedures relating to surgery, care, and use of animals for experiments were approved by an animal care committee of the French Ministry of Agriculture, in accordance with French regulations (decree-law 2001-464, May 29, 2001). Cows were housed in individual tie stalls and had free access to water throughout the trial. The cows were milked twice daily at 0700 and $1730 \mathrm{~h}$.

\section{Experimental Treatments and Feeding Management}

Six TMR differing in F:C and amount of rapidly degradable carbohydrates from the concentrate were formulated. The $3 \mathrm{~F}: \mathrm{C}$ were 20:80, 35:65, and 50:50, and they were combined with slowly and rapidly rumendegradable concentrates ( $\mathbf{S}$ and $\mathbf{R}$, respectively). The composition of the various TMR were 1) low forage and slowly degradable concentrate (S20), 2) low forage and rapidly degradable concentrate $(\mathbf{R 2 0}), 3)$ medium forage and slowly degradable concentrate (S35), 4) medium forage and rapidly degradable concentrate (R35), 5) high forage and slowly degradable concentrate (S50), and 6) high forage and rapidly degradable concentrate (R50).

The content of rapidly degradable DM (RDM) of each feedstuff (\%) was defined as its content in DM disappearing during the first $4 \mathrm{~h}$ of in sacco incubation. Rapidly degradable DM was calculated from in sacco degradation parameters $(a, b$, and $c)$ of DM, which were compiled in the tables of composition and nutritional value of feed materials (INRA-AFZ, 2004):

$$
R D M=a+b \times\left(1-\mathrm{e}^{-c t}\right),
$$

where $a=$ soluble DM fractions (\%); $b=$ slowly disappearing DM fractions (\%); $c=$ fractional rate of disappearance of DM; and $t=$ time of incubation $(4 \mathrm{~h})$.

The concentrates were formulated to provide approximately 20 and $30 \%$ of rapidly degradable DM, respectively, in $\mathrm{S}$ and $\mathrm{R}$ TMR. The dietary RDM from the concentrate (CRDM) was calculated according to the formula

$$
C R D M=\sum_{i=1}^{n} p i \times R D M i
$$

where $R D M i$ represents the content of RDM of feedstuff $i, p i$ is the dietary proportion of feedstuff $i$, and $n$ 
Table 1. Composition of the total mixed diets (DM basis)

\begin{tabular}{|c|c|c|c|c|c|c|}
\hline \multirow[b]{2}{*}{ Item } & \multicolumn{6}{|c|}{ Treatment $^{1}$} \\
\hline & S50 & S35 & $\mathrm{S} 20$ & R50 & $\mathrm{R} 35$ & $\mathrm{R} 20$ \\
\hline \multicolumn{7}{|l|}{ Ingredients (\%) } \\
\hline Corn silage & 49.2 & 34.4 & 19.7 & 49.2 & 34.4 & 19.7 \\
\hline Soybean hulls & 4.1 & 12.3 & 20.7 & - & 7.7 & 10.8 \\
\hline Corn & 23.6 & 29.2 & 38.7 & - & 7.9 & 17.7 \\
\hline Wheat & - & - & - & 24.6 & 18.7 & 15.7 \\
\hline Wheat bran & 3.9 & 6.9 & - & 3.0 & 18.7 & 17.7 \\
\hline Citrus pulp & 4.9 & - & - & 9.2 & - & - \\
\hline Wheat straw & - & 3.9 & 7.9 & - & - & 5.9 \\
\hline Soybean meal & 3.9 & 3.9 & 3.9 & 3.9 & 3.9 & 3.9 \\
\hline Formaldehyde-treated soybean meal & 6.4 & 5.2 & 4.6 & 6.1 & 4.9 & 4.4 \\
\hline Beet molasses & 1.0 & 1.3 & 1.6 & 1.0 & 1.3 & 1.6 \\
\hline Soybean oil & 0.4 & 0.4 & 0.4 & 0.4 & 0.4 & 0.4 \\
\hline Urea & 0.9 & 0.8 & 1.0 & 1.0 & 0.5 & 0.5 \\
\hline Mineral-vitamin premix ${ }^{2}$ & 1.2 & 1.2 & 1.2 & 1.2 & 1.2 & 1.2 \\
\hline Calcium carbonate & 0.4 & 0.4 & 0.4 & 0.4 & 0.4 & 0.4 \\
\hline \multicolumn{7}{|l|}{ Chemical composition (\%) } \\
\hline $\mathrm{DM}$ & 50.9 & 58.1 & 68.4 & 50.9 & 58.2 & 68.3 \\
\hline $\mathrm{OM}$ & 94.1 & 94.1 & 94.2 & 94.1 & 94.2 & 94.0 \\
\hline $\mathrm{CP}(\mathrm{N} \times 6.25)$ & 15.2 & 15.9 & 16.5 & 15.4 & 16.2 & 16.1 \\
\hline NDF & 27.8 & 30.2 & 29.2 & 26.1 & 29.6 & 30.2 \\
\hline $\mathrm{ADF}$ & 14.9 & 16.5 & 17.1 & 13.8 & 14.3 & 15.3 \\
\hline Acid detergent lignin & 1.5 & 1.9 & 1.7 & 1.6 & 1.9 & 2.0 \\
\hline Starch & 36.7 & 35.3 & 36.2 & 36.9 & 35.3 & 35.1 \\
\hline Starch from corn silage & 17.6 & 12.3 & 7.0 & 17.6 & 12.3 & 7.0 \\
\hline \multicolumn{7}{|l|}{ Nutritional value } \\
\hline $\mathrm{NE}_{\mathrm{L}}(\mathrm{Mcal} / \mathrm{kg})$ & 1.75 & 1.72 & 1.68 & 1.75 & 1.73 & 1.70 \\
\hline $\operatorname{PDIE}^{3}(\mathrm{~g} / \mathrm{kg})$ & 99 & 102 & 102 & 96 & 99 & 100 \\
\hline $\operatorname{PDIN}^{4}(\mathrm{~g} / \mathrm{kg})$ & 99 & 105 & 108 & 99 & 105 & 106 \\
\hline
\end{tabular}

${ }^{1}$ Treatments: S50, S35, S20 = slowly degradable concentrate combined with 50:50, 35:65, and 20:80 forage-toconcentrate ratio, respectively; R50, R35, R20 = rapidly degradable concentrate combined with 50:50, 35:65, and 20:80 forage-to-concentrate ratio, respectively.

${ }^{2}$ Contained $52 \%$ calcium carbonate, $23 \%$ dicalcium phosphate, $10 \%$ calcium and magnesium phosphate, $9 \%$ cane molasses, $6 \%$ magnesia oxide, $600 \mathrm{kIU} / \mathrm{kg}$ of vitamin A, $80 \mathrm{kIU} / \mathrm{kg}$ of vitamin $\mathrm{D}_{3}, 1,500 \mathrm{mg} / \mathrm{kg}$ of vitamin $\mathrm{E}, 4,000 \mathrm{mg} / \mathrm{kg}$ of $\mathrm{Zn}, 4,000 \mathrm{mg} / \mathrm{kg}$ of $\mathrm{Mn}, 1,000 \mathrm{mg} / \mathrm{kg}$ of $\mathrm{Cu}$ (sulfate and chelate), $80 \mathrm{mg} / \mathrm{kg}$ of I, $20 \mathrm{mg} / \mathrm{kg}$ of Co, and $20 \mathrm{mg} / \mathrm{kg}$ of Se.

${ }^{3}$ Digestible protein in the small intestine supplied by microbial protein from rumen-fermented OM (INRA, 1989).

${ }^{4}$ Digestible protein in the small intestine supplied by microbial protein from rumen-degradable protein (INRA, 1989).

is the number of feedstuffs in the concentrate mixture of TMR.

Because wheat and citrus pulp contain a great amount of RDM (respectively, 68 and $53 \%$ DM), they were used in $\mathrm{R}$ diets as the main sources of starch and fiber, respectively. Because corn grain and soybean hulls contain a lesser amount of RDM (respectively, 35 and $20 \% \mathrm{DM}$ ), they were used in S diets as the main sources of starch and fiber, respectively. Wheat straw was added in the S35, S20, and R20 diets to adjust the energy and NDF contents.

The concentrates were also formulated to obtain 6 TMR supplying a similar amount of starch (35\% of $\mathrm{DM})$, total $\mathrm{NDF}(29 \%$ of $\mathrm{DM}), \mathrm{NE}_{\mathrm{L}}(1.73 \mathrm{Mcal} / \mathrm{kg}$ of $\mathrm{DM})$, and protein digestible in the small intestine $(10 \%$ of DM; INRA, 1989). The diets were supplemented with $300 \mathrm{~g} / \mathrm{d}$ of a mineral premix $(5.5 \% \mathrm{P}, 27 \% \mathrm{Ca}$, and $4 \% \mathrm{Mg}$ ) and $100 \mathrm{~g} / \mathrm{d}$ of calcium carbonate to meet mineral requirements (INRA, 1989).

The 6 concentrates were pelleted including soybean meal and urea to facilitate the distribution of the TMR. Corn silage (MONTOP variety, NK Semences, Syngenta Seeds, Saint-Sauveur, France) was used as the sole forage source. It was harvested as a whole crop silage on a single day (October 8, 2007). A Claas 870 forage harvester (Claas, Harsewinkel, Germany) was used to obtain silage chopped at a theoretical chop length of $14 \mathrm{~mm}$. The composition of the 6 diets is given in Table 1.

The diets were fed in 2 equally sized meals per day at 0800 and $1800 \mathrm{~h}$. The amount of feed offered was individually fixed at $100 \%$ of the DM ingested during the preexperimental period when cows were fed a diet based on corn silage with the proportion of forage 
decreasing progressively from 65 to $45 \%$. Cows had free access to the mangers from 0800 to $1130 \mathrm{~h}$ and from 1700 to $0200 \mathrm{~h}$ to display prominent differences between diets in ruminal fermentation kinetics and to prevent the appearance of small meals during the day.

\section{Sampling Schedule and Procedure}

Feeds and Orts. Voluntary DMI was individually recorded daily during the experiment. Orts were collected and weighed daily before the morning feeding. To adjust the proportion of corn silage in the diet and to calculate DMI, the DM content of concentrates $\left(80^{\circ} \mathrm{C}\right.$, $48 \mathrm{~h}$ ) was determined weekly, whereas the DM content of corn silage and orts were determined every day. To determine the chemical composition of corn silage, one representative sample of the whole silo was produced by sampling $1 \mathrm{~kg}$ weekly. The samples were kept frozen and pooled at the end of the experiment. Half of the sample was freeze-dried before proximal analyses, and half was used to determine the fermentative profile of the silo. Weekly samples of concentrates were also pooled over the entire experimental period for proximal analyses.

For determining particle size distribution, $500 \mathrm{~g}$ of corn silage was stored daily at $4^{\circ} \mathrm{C}$ and pooled at the end of each experimental period during $14 \mathrm{~d}$. A large sample $(800 \mathrm{~g})$ of corn silage was sieved in duplicate on 20- and 10-mm sieves using a manual shaker (Institut Technique des Céréales et des Fourrages, Paris, France). Then, particle size distribution of material that passed the $10-\mathrm{mm}$ sieve was determined by dry-sieving using an electromagnetic sieve shaker (Analysette 3, Fritsch, Oberstein, Germany). Four sieve sizes were employed $(4,2,1$, and $0.5 \mathrm{~mm})$. The cumulative proportion of particles retained on the $4-\mathrm{mm}$ sieve was obtained by adding the proportions of particles retained on the $20-, 10-$, and 4-mm sieves. The proportion of particles retained on the 2 -mm sieve was also included to determine the cumulative proportion of particles retained on the 2 -mm sieve. The proportion of NDF from particles retained on a 4-mm $\left(\mathbf{F} \mathbf{N D F}_{4}\right)$ or 2 -mm sieve $\left(\mathbf{F N D F}{ }_{2}\right)$ was determined by multiplying NDF content of corn silage by the corresponding cumulative proportion of particles. Particle size distribution of corn silage was also determined using the Penn State Particle Separator (PSPS). The physical effectiveness factor (pef) of corn silage was calculated as the sum of the proportion of DM retained on 2 sieves: 19 and $8 \mathrm{~mm}$ (pef $_{8.0}$; Lammers et al., 1996) or on 3 sieves: 19, 8, and 1.18 $\mathrm{mm}\left(\right.$ pef $_{1.18}$; Kononoff et al., 2003). The peNDF ${ }_{8.0}$ and peNDF $_{1.18}$ were calculated by multiplying NDF content of corn silage by pef $_{8.0}$ and pef ${ }_{1.18}$, respectively.
Chewing Activity. The daily pattern of eating and ruminating times was monitored over $24 \mathrm{~h}$ by recording the jaw movements with a portable device (Brun et al., 1984). All cows were equipped simultaneously on d 10 to 13 with a small balloon filled with foam rubber placed in the submandibular space and connected to a pressure transducer. A rumination bout was defined as a succession of at least 5 boli, defined as a regular combination of a sequence of $2.5 \mathrm{~s}$ without jaw movements (regurgitation of the bolus) and subsequent sequences of $2.5 \mathrm{~s}$ with jaw movements. A meal was defined as a period of the remaining activity lasting at least $7 \mathrm{~min}$ and separated from another meal by at least 7 min (Brun et al., 1984). The average time spent eating or ruminating per kilogram of DM or FNDF intake was calculated by dividing the total daily time of each activity (eating or ruminating) by the mean daily DM or FNDF intake of the measurement days, respectively.

Ruminal $\boldsymbol{p H}$ and Fermentation. Rumen fluid was sampled $(50 \mathrm{~mL})$ from the ventral sac at 0800 (before the meal), 0830, 0900, 0930, 1000, 1030, 1100, 1130, $1200,1300,1400,1500,1600$, and $1700 \mathrm{~h}$ on d 13 . At each sampling time, $\mathrm{pH}$ was measured immediately, and the samples were strained through 6 layers of cheesecloth. For VFA analysis, a second sample of $4 \mathrm{~mL}$ was mixed with $0.4 \mathrm{~mL}$ of $5 \%$ (wt/vol) orthophosphoric acid. For lactate analysis, $10 \mathrm{~mL}$ of ruminal fluid was sampled at 0800, 0900, 1000, 1100, 1200, 1300, 1400, 1500, 1600, and $1700 \mathrm{~h}$ without preservative. The samples were stored at $-20^{\circ} \mathrm{C}$. For $\mathrm{NH}_{3}$ analysis, $4 \mathrm{~mL}$ of strained rumen fluid was mixed with $4 \mathrm{~mL}$ of $20 \%$ (wt/vol) $\mathrm{NaCl}$.

Rumen Liquid Passage Rate. To determine the fractional outflow rate of liquid and rumen liquid volume, all cows were pulse dosed through the rumen fistulae on d 10 at $1130 \mathrm{~h}$ with $50 \mathrm{~g}$ of $\mathrm{LiCo}(\mathrm{II}) \mathrm{EDTA}$ (Uden et al., 1980) diluted in $2 \mathrm{~L}$ of water. The rumen fluid was collected at 1330, 1530, 1800, and $2100 \mathrm{~h}$ on d 10 and at 0700 and $1400 \mathrm{~h}$ on d 11. At each sampling time, $10 \mathrm{~mL}$ of strained rumen fluid was centrifuged $\left(4,500 \mathrm{rpm}\right.$, at $4^{\circ} \mathrm{C}$ for $\left.15 \mathrm{~min}\right)$ and frozen at $-20^{\circ} \mathrm{C}$ for cobalt analyses. Fractional liquid outflow rate was calculated from the declining slope of the natural logarithm of Co concentration over time after dosing. Rumen liquid volume was calculated by dividing the quantity of Co dosed in the rumen by the calculated concentration at zero time. Flow of liquid out of the rumen was calculated by multiplying rumen liquid volume and fractional outflow rate.

Cellulolytic Activity. Disappearance of soybean hulls DM incubated in nylon bags was used as an index of fibrolytic activity of the rumen. On $\mathrm{d} 12,3 \mathrm{~g}$ of soybean hulls ground through a $0.8-\mathrm{mm}$ screen was in- 
serted into the nylon bag $(6 \times 11 \mathrm{~cm}$, pore size $=0.050$ $\mathrm{mm})$. The bags were introduced into the rumen before the morning meal $(0800 \mathrm{~h})$ and incubated for $24 \mathrm{~h}$. After removal, the bags were washed with cold water in a washing machine ( 3 times for periods of $5 \mathrm{~min}$ ) and then oven-dried $\left(48 \mathrm{~h}, 80^{\circ} \mathrm{C}\right)$. Two bags were used per cow.

Total-Tract Digestibility. To determine digestibility, daily total fresh fecal output was collected separately from urine from d 10 to 13 as described by Peyraud et al. (1997) and weighed. A daily sample (1\% of fresh weight) was dried for DM determination $\left(80^{\circ} \mathrm{C}\right.$, $72 \mathrm{~h}$ ). Two additional samples were composited and freeze-dried for proximal analyses.

Milk Production and Composition. Milk production was recorded at each milking. Protein and fat content were determined by infrared analysis (Milkoscan, Foss Electric, Hillerød, Denmark) on individual samples collected on 8 successive milkings each week. On d 13, $100 \mathrm{~mL}$ of milk was sampled at the morning milking for analysis of fatty acids composition. Milk fatty acids were analyzed according to Apper-Bossard et al. (2006).

\section{Chemical Analyses}

Analyses were performed on mean dry samples of feeds, feed refusals, and feces. All samples were ground with a 3-blade knife mill (Retsch GmbH, Haan, Germany) through a $0.8-\mathrm{mm}$ screen. Organic matter content was determined by ashing at $550^{\circ} \mathrm{C}$ for $6 \mathrm{~h}$. Nitrogen was obtained by the Kjeldhal method. Neutral detergent fiber, ADF, and acid detergent lignin were analyzed on a Fibersac M extraction unit (Ankom Technology, Fairport, NY) after hydrolysis of starch with $\alpha$-amylase (Ankom) as described in Le Liboux and Peyraud (1999). Starch was determined by Ewers's polarimetric method (Association Française de Normalisation, 1985).

The VFA concentration and profile were determined by gas chromatography as described by Hurtaud et al. (1993) using a gas liquid chromatograph (Varian 3400, Varian SA, Les Ulis, France) on a column (1.5-m long $\times 2$-mm i.d.) packed with 80/100 mesh Chromosorb 101 (Stabilwax DA, Rostek France, Lisse, France) and nitrogen as carrier gas. Ammonia in ruminal contents was determined by the method described in Le Liboux and Peyraud (1999). D- and L-lactate were determined using an enzymatic method (Enzytec D/L-Lactic Acid, Scil Diagnostics GmbH, Viernheim, Germany). For Co analysis, centrifuged rumen fluid was pumped directly and analyzed according to the flame atomic spectrometry analytical method (Varian, Varian Australia Pty. Ltd., Mulgrave, Victoria, Australia).
Table 2. Particle size distribution of corn silage (DM basis)

\begin{tabular}{lc}
\hline Item & Amount \\
\hline Penn State Particle Separator $^{1}$ & \\
\% of DM retained on sieves & \\
$19 \mathrm{~mm}$ & 5.5 \\
$8 \mathrm{~mm}$ & 67.4 \\
$1.18 \mathrm{~mm}$ & 24.1 \\
Pan & 3.0 \\
pef $_{8.0}$ & 72.9 \\
pef $_{1.18}$ & 97.0 \\
peNDF $_{8.0}$ & 28.0 \\
peNDF $_{1.18}$ & 37.2 \\
Oscillating sieve shaker $^{2}$ & \\
of DM retained on sieves & \\
$20 \mathrm{~mm}$ & 3.1 \\
$10 \mathrm{~mm}$ & 19.9 \\
$4 \mathrm{~mm}$ & 49.7 \\
$2 \mathrm{~mm}$ & 17.1 \\
$1 \mathrm{~mm}$ & 7.0 \\
$<1 \mathrm{~mm}$ & 3.2 \\
$>4 \mathrm{~mm}$ & 72.7 \\
$>2 \mathrm{~mm}$ & 89.8 \\
$\mathrm{FNDF}_{4}$ & 27.9 \\
$\mathrm{FNDF}_{2}$ & 34.5 \\
\hline
\end{tabular}

${ }^{1}$ Particle size distribution of corn silage measured using the Penn State Particle Separator (Kononoff et al., 2003); pef $_{8.0}$ and pef $_{1.18}=$ physical effectiveness factor determined as the proportion of particles retained on 2 sieves (19 and $8 \mathrm{~mm}$; Lammers et al., 1996) and 3 sieves (19, 8 , and $1.18 \mathrm{~mm}$; Kononoff et al., 2003), respectively; peNDF ${ }_{8.0}$ and peNDF $_{1.18}=$ physically effective NDF determined as NDF content of corn silage multiplied by pef $_{8.0}$ and pef $_{1.18}$, respectively.

${ }^{2}$ Particle size distribution of corn silage measured using a manual shaker equipped with 2 sieves (20 and $10 \mathrm{~mm}$ ) and a vertical oscillating sieve shaker equipped with a stack of sieves arranged in descending mesh size $(4,2,1$, and $0.5 \mathrm{~mm}) ;>4 \mathrm{~mm}$ and $>2 \mathrm{~mm}=$ cumulative proportion of particles retained on a $4-\mathrm{mm}$ and a $2-\mathrm{mm}$ sieve, respectively; $\mathrm{FNDF}_{4}$ and $\mathrm{FNDF}_{2}=\mathrm{NDF}$ content of corn silage multiplied by cumulative proportion of particles retained on $>4-\mathrm{mm}$ and $>2-\mathrm{mm}$ sieves, respectively.

\section{Calculations}

Given that the spot values of ruminal $\mathrm{pH}$, total VFA concentration, molar proportions of the different VFA, and $\mathrm{NH}_{3}$ concentration were separated by half an hour at the beginning of the kinetics and by an hour at the end of the kinetics, the mean values of these parameters were calculated by weighting each spot value by the time separating 2 successive samplings $(0.5 \mathrm{~h}$ from 0800 to $1130 \mathrm{~h}$ and $1 \mathrm{~h}$ from 1200 to $1700 \mathrm{~h}$ ).

Because the $\mathrm{pH}$ curves exhibited a concave asymmetric shape, the time evolution of $\mathrm{pH}$ was fitted to a third-degree polynomial function:

$$
\mathrm{pH}_{t}=a t^{3}+b t^{2}+c t+d,
$$

where $t=$ time postfeeding $(\mathrm{h})$ and $\mathrm{pH}_{t}=$ value of the ruminal $\mathrm{pH} t$ hours postfeeding.

The PROC REG procedure of SAS (SAS Institute, 1999) was used to fit polynomial equations to each curve 
Table 3. Physical composition and content of rapidly degradable DM from concentrate (CRDM) of the total mixed diets (\% DM basis)

\begin{tabular}{|c|c|c|c|c|c|c|}
\hline \multirow[b]{2}{*}{ Item } & \multicolumn{6}{|c|}{ Treatment $^{1}$} \\
\hline & $\mathrm{S} 50$ & S35 & $\mathrm{S} 20$ & $\mathrm{R} 50$ & R35 & $\mathrm{R} 20$ \\
\hline peNDF $_{8.0}$ from forage ${ }^{2}$ & 13.7 & 9.6 & 5.5 & 13.7 & 9.6 & 5.5 \\
\hline peNDF $_{1.18}$ from forage ${ }^{2}$ & 18.3 & 12.8 & 7.3 & 18.3 & 12.8 & 7.3 \\
\hline $\mathrm{FNDF}_{4}{ }^{3}$ & 13.7 & 9.6 & 5.5 & 13.7 & 9.6 & 5.5 \\
\hline $\mathrm{FNDF}_{2}{ }^{3}$ & 16.9 & 11.8 & 6.8 & 16.9 & 11.8 & 6.8 \\
\hline $\mathrm{FNDF}^{4}$ & 18.9 & 13.2 & 7.6 & 18.9 & 13.2 & 7.6 \\
\hline CRDM & 17.9 & 20.5 & 22.4 & 27.3 & 30.2 & 32.2 \\
\hline
\end{tabular}

${ }^{1}$ Treatments: S50, S35, S20 = slowly degradable concentrate combined with 50:50, 35:65, and 20:80 forage-toconcentrate ratio, respectively; $\mathrm{R} 50, \mathrm{R} 35, \mathrm{R} 20$ = rapidly degradable concentrate combined with 50:50, 35:65, and 20:80 forage-to-concentrate ratio, respectively.

${ }^{2}$ Particle size distribution of corn silage measured using the Penn State Particle Separator (Kononoff et al., 2003); pef $_{80}$ and pef $_{1.18}=$ physical effectiveness factor determined as the proportion of particles retained on 2 sieves (19 and $8 \mathrm{~mm}$; Lammers et al., 1996) and 3 sieves (19, 8, and $1.18 \mathrm{~mm}$; Kononoff et al., 2003), respectively; peNDF $_{8.0}$ and peNDF $_{1.18}=$ physically effective NDF determined as NDF content of corn silage multiplied by pef $_{8.0}$ and pef $_{1.18}$, respectively.

${ }^{3}$ Particle size distribution of corn silage measured using a manual shaker equipped with 2 sieves (20 and $10 \mathrm{~mm}$ ) and a vertical oscillating sieve shaker equipped with a stack of sieves arranged in descending mesh size $(4,2,1$, and $0.5 \mathrm{~mm}) ; \mathrm{FNDF}_{4}$ and $\mathrm{FNDF}_{2}=\mathrm{NDF}$ content of corn silage multiplied by cumulative proportion of particles retained on $>4-\mathrm{mm}$ and $>2-\mathrm{mm}$ sieves, respectively.

${ }^{4} \mathrm{FNDF}=\mathrm{NDF}$ from forage.

of the $\mathrm{pH}$ data set. All coefficients were taken into account even if they were statistically nonsignificant in the equation. The 4 coefficients $(a, b, c, d)$ were used to calculate the initial $\mathrm{pH}$ at $0800 \mathrm{~h}$ (just before the beginning of the morning meal), the rate of $\mathrm{pH}$ drop at $0800 \mathrm{~h}$ (initial rate of $\mathrm{pH}$ drop), the postfeeding amplitude of $\mathrm{pH}$ perturbations ( $\mathrm{pH}$ range) by the difference between the initial $\mathrm{pH}$ and minimal $\mathrm{pH}$ calculated at a time when the first derivative was nil, the time during which the $\mathrm{pH}$ was below 6.0 and 5.8 , and the area under the curve of $\mathrm{pH} 6.0$ and 5.8. The kinetic parameters of VFA were analyzed in the same way to calculate the initial rate of VFA increase and the VFA range.

\section{Statistical Analyses}

All data were analyzed as a $6 \times 6$ Latin square with a factorial arrangement of treatments using PROC MIXED of SAS (SAS Institute, 1999). The model included treatments (F:C and $\mathrm{CRDM}$ ), the interaction between F:C and CRDM, and period as fixed effects and cow as random effect. All means presented are least squares means. The sums of squares of the F:C and $\mathrm{F}: \mathrm{C} \times \mathrm{CRDM}$ effects were further partitioned into comparisons with a single degree of freedom to provide linear and quadratic effects of $\mathrm{F}: \mathrm{C}$ and $\mathrm{F}: \mathrm{C} \times \mathrm{CRDM}$ using the orthogonal polynomial method (Gill, 1978). Because the quadratic effects of $\mathrm{F}: \mathrm{C} \times \mathrm{CRDM}$ were never significant, the probabilities of this contrast are not presented in the tables. The PROC REG of SAS was used to establish the regression models predicting ruminal and milk parameters with FNDF and CRDM. Pearson correlation coefficients between ruminal parameters were estimated using the CORR procedure of SAS. Effects of the factors were declared significant at $P<0.05$ unless otherwise noted.

\section{RESULTS}

\section{Chemical and Physical Composition of the Diets}

The DM of corn silage averaged $35.4 \%$. The silage was well preserved with a mean $\mathrm{pH}$ averaging 3.9 . Lactic acid, acetic acid, and propionic acid were, respectively, $5.2,0.1$, and $0.04 \%$ of DM. On a DM basis, the corn silage contained $35.8 \%$ starch, $38.4 \% \mathrm{NDF}$, and $6.8 \% \mathrm{CP}$.

The physical description of corn silage used in the experiment is presented in Table 2. The cumulative proportion of DM retained on the 8-mm sieve of the PSPS was similar to the cumulative proportion of DM retained on the 4-mm sieve of the oscillating sieve shaker and averaged $73 \%$. The cumulative proportion of particles retained on the $1.18-\mathrm{mm}$ sieve of the PSPS was greater than that retained on the $2-\mathrm{mm}$ sieve of the oscillating sieve shaker (97.0 vs. $89.8 \%$, respectively, for the PSPS and the oscillating sieve shaker). Finally, all criteria calculated to characterize the peNDF from the forage in the experimental diets (Table 3) were closely linked. It should be noted that peNDF ${ }_{1.18}$ from forage and FNDF were numerically similar and decreased proportionally to F:C (Table 3), with 18.9, 13.2, and 
Table 4. Effects of forage-to-concentrate ratio (F:C) and dietary content of rapidly degradable DM from concentrate (CRDM) on intake of DM, $\mathrm{OM}$, cell wall constituents, starch, $\mathrm{CP}$, and CRDM

\begin{tabular}{|c|c|c|c|c|c|c|c|c|c|c|c|}
\hline \multirow{2}{*}{ Item } & \multirow{2}{*}{\multicolumn{6}{|c|}{ Treatment $^{1}$}} & \multirow{2}{*}{ SEM } & \multicolumn{4}{|c|}{$P$-value ${ }^{2}$} \\
\hline & & & & & & & & \multicolumn{2}{|c|}{$\mathrm{F}: \mathrm{C}$} & CRDM & $\frac{\mathrm{F}: \mathrm{C} \times \mathrm{CRDM}}{\mathrm{L}}$ \\
\hline $\mathrm{DM}(\mathrm{kg} / \mathrm{d})$ & 22.5 & 24.0 & 23.9 & 20.1 & 22.1 & 22.0 & 0.81 & 0.001 & 0.02 & $<0.001$ & 0.57 \\
\hline As concentrate & 11.4 & 15.8 & 19.2 & 10.2 & 14.5 & 17.6 & 0.52 & $<0.001$ & 0.04 & $<0.001$ & 0.57 \\
\hline As corn silage & 11.1 & 8.2 & 4.7 & 9.9 & 7.6 & 4.3 & 0.31 & $<0.001$ & 0.02 & $<0.001$ & 0.04 \\
\hline $\operatorname{ADF}(\mathrm{kg} / \mathrm{d})$ & 3.2 & 4.0 & 4.1 & 2.6 & 3.1 & 3.4 & 0.12 & $<0.001$ & 0.001 & $<0.001$ & 0.53 \\
\hline Starch $(\mathrm{kg} / \mathrm{d})$ & 8.3 & 8.5 & 8.6 & 7.5 & 7.8 & 7.7 & 0.30 & 0.15 & 0.55 & $<0.001$ & 0.71 \\
\hline $\mathrm{CP}(\mathrm{kg} / \mathrm{d})$ & 3.5 & 3.8 & 4.0 & 3.2 & 3.6 & 3.6 & 0.13 & $<0.001$ & 0.01 & $<0.001$ & 0.42 \\
\hline $\mathrm{FNDF}^{3}(\mathrm{~kg} / \mathrm{d})$ & 4.3 & 3.2 & 1.8 & 3.8 & 2.9 & 1.7 & 0.12 & $<0.001$ & 0.03 & $<0.001$ & 0.06 \\
\hline CRDM (kg/d) & 4.0 & 4.9 & 5.3 & 5.5 & 6.7 & 7.1 & 0.21 & $<0.001$ & 0.005 & $<0.001$ & 0.26 \\
\hline
\end{tabular}

${ }^{1}$ Treatments: S50, S35, S20 = slowly degradable concentrate combined with 50:50, 35:65, and 20:80 forage-to-concentrate ratio, respectively; $\mathrm{R} 50, \mathrm{R} 35, \mathrm{R} 20$ = rapidly degradable concentrate combined with 50:50, 35:65, and 20:80 forage-to-concentrate ratio, respectively.

${ }^{2} \mathrm{~L}=$ linear; $\mathrm{Q}=$ quadratic.

${ }^{3} \mathrm{FNDF}=\mathrm{NDF}$ from forage.

$7.6 \%$ of FNDF, respectively, for a high, medium, and low F:C.

Rapidly degradable DM from concentrate was greater for $\mathrm{R}$ than for $\mathrm{S}$ diets. Decreasing F:C moderately increased CRDM, whereas the NDF content of the diet was marginally increased (Table 1).

\section{Intake}

Data on daily intake are presented in Table 4. Dry matter, OM, fiber, and $\mathrm{CP}$ intake increased when $\mathrm{F}: \mathrm{C}$ decreased from 50:50 to 35:65 but remained unaffected when F:C further decreased to 20:80. The starch intake was not affected by F:C. Feeding $\mathrm{R}$ diets reduced DM, $\mathrm{OM}, \mathrm{ADF}$, starch, and CP intake $(P<0.001)$. Feeding $\mathrm{R}$ diets also reduced NDF intake and did so to a greater extent when cows were given feed with a high $\mathrm{F}: \mathrm{C}$ (interaction $\mathrm{F}: \mathrm{C} \times \mathrm{CRDM}, P<0.01$ ).

Corn silage intake and, thus, FNDF intake declined when $\mathrm{F}: \mathrm{C}$ decreased, the rate of decline being greater between a medium and low $\mathrm{F}: \mathrm{C}$ than between a high and medium F:C. When feeding $\mathrm{R}$ diets, corn silage and

Table 5. Effects of forage-to-concentrate ratio (F:C) and dietary content of rapidly degradable DM from concentrate (CRDM) on feeding behavior

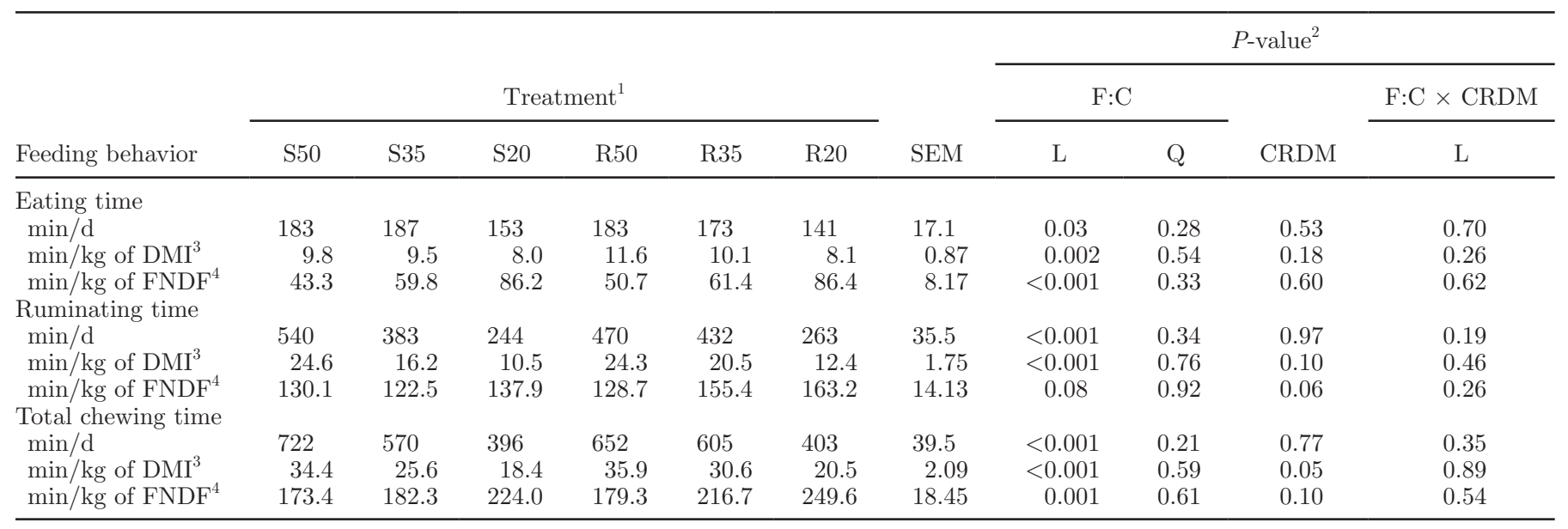

${ }^{1}$ Treatments: S50, S35, S20 = slowly degradable concentrate combined with 50:50, 35:65, and 20:80 forage-to-concentrate ratio, respectively; $\mathrm{R} 50, \mathrm{R} 35, \mathrm{R} 20$ = rapidly degradable concentrate combined with 50:50, 35:65, and 20:80 forage-to-concentrate ratio, respectively.

${ }^{2} \mathrm{~L}=$ linear; $\mathrm{Q}=$ quadratic.

${ }^{3}$ Related to DMI for the same days of feeding behavior recording.

${ }^{4}$ Related to NDF from forage (FNDF) intake for the same days of feeding behavior recording. 
FNDF intake also decreased, and the decline between a high and medium F:C was lesser than between a medium and low F:C. The concentrate intake increased when $\mathrm{F}$ : $\mathrm{C}$ was decreased, the rate of increase being greater between a high and medium than between a medium and low F:C. The concentrate intake decreased but the CRDM intake increased when feeding $\mathrm{R}$ diets.

\section{Chewing Activity}

Data on feeding behavior are presented in Table 5 . Time spent eating and ruminating and total time spent chewing $(\mathrm{min} / \mathrm{d})$ decreased linearly when $\mathrm{F}$ :C decreased and were not affected by CRDM. The average time spent eating, ruminating, and chewing per kilogram of DMI decreased linearly when F:C decreased $(P<$ $0.001)$. A $10 \%$ decrease in $\mathrm{F}: \mathrm{C}$ decreased the average time spent chewing per kilogram of DMI by $5.2 \mathrm{~min} /$ $\mathrm{kg}$ of DMI. Feeding $\mathrm{R}$ diets moderately increased the average time spent chewing per kilogram of DMI $(P$ $<0.05)$ and tended to increase the average time spent ruminating per kilogram of DMI without affecting the average time spent eating per kilogram of DMI. The average eating time and total chewing time per kilogram of FNDF ingested increased linearly when F:C decreased, whereas it was just a tendency for ruminating time. Increasing CRDM had only a limited effect on the average ruminating time and total chewing time per kilogram of FNDF ingested.

\section{Ruminal $\mathrm{pH}$ and Fermentation}

The effects of F:C and CRDM on ruminal fermentation are presented in Table 6, Figure 1, Figure 2, and Figure 3. The initial $\mathrm{pH}$ (before the morning meal) was not affected by the treatments. Decreasing F:C led to a linear decrease in mean ruminal $\mathrm{pH}(-0.10 \mathrm{pH}$ unit $/ 10 \%$ decrease in F:C, $P<0.001)$ and minimum $\mathrm{pH}$. Decreasing F:C linearly increased the $\mathrm{pH}$ range $(P$ $=0.02)$; the time during which the $\mathrm{pH}$ was below 6.0 and 5.8; the area under the curve of $\mathrm{pH} 6.0$ and 5.8 $(P<0.001)$; and the mean concentrations of VFA $(P$ $=0.01)$, L-lactate, and D-lactate $(P<0.001)$. It was noticeable that total lactate concentration exhibited

Table 6. Effects of forage-to-concentrate ratio (F:C) and dietary content of rapidly degradable DM from concentrate (CRDM) on ruminal pH and fermentation characteristics of dairy cows throughout a feeding cycle

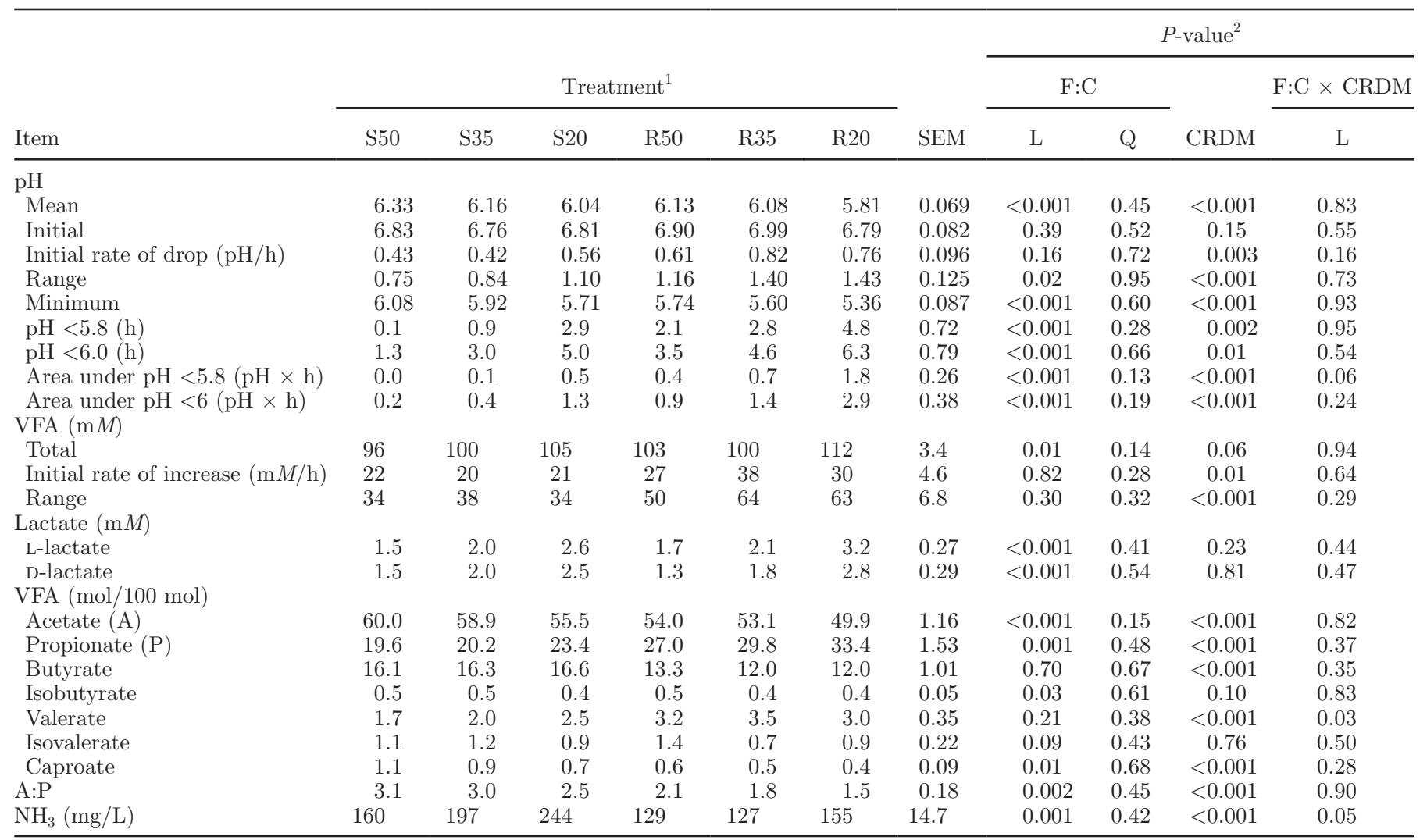

${ }^{1}$ Treatments: S50, S35, S20 = slowly degradable concentrate combined with 50:50, 35:65, and 20:80 forage-to-concentrate ratio, respectively; R50, R35, R20 = rapidly degradable concentrate combined with 50:50, 35:65, and 20:80 forage-to-concentrate ratio, respectively.

${ }^{2} \mathrm{~L}=$ linear; $\mathrm{Q}=$ quadratic. 


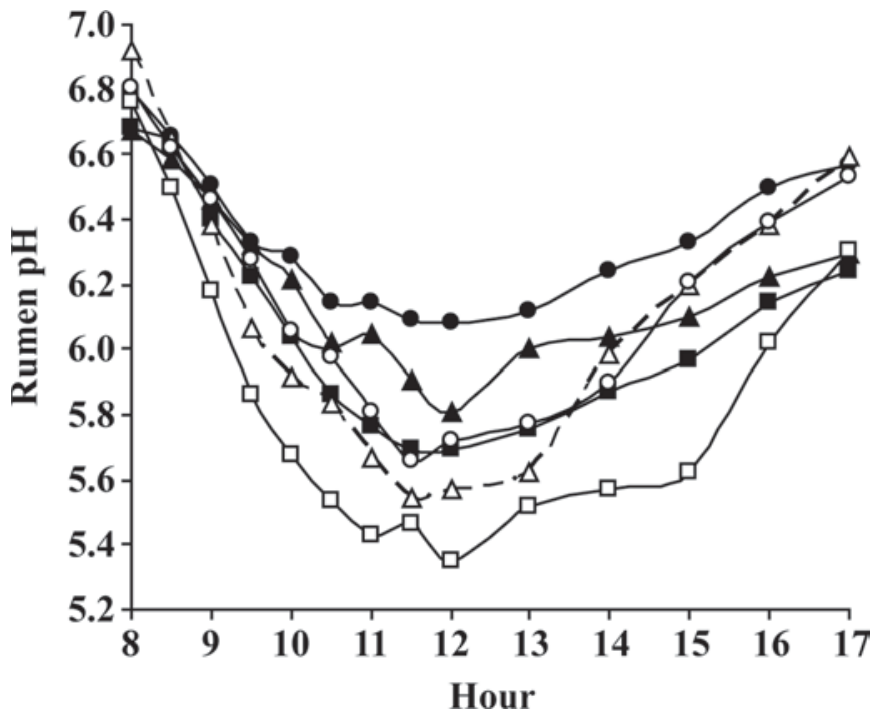

Figure 1. Postfeeding fluctuations in ruminal $\mathrm{pH}$ for diets differing in forage-to-concentrate ratio and rapidly degradable DM from concentrate. S50: ๑; S35: $\mathbf{\Delta}$; S20: $\mathbf{\square}$; R50: O; R35: $\Delta$; R20: $\square$. S50, S35, S20 = slowly degradable concentrate combined with 50:50, 35:65, and 20:80 forage-to-concentrate ratio, respectively; R50, R35, R20 = rapidly degradable concentrate combined with 50:50,35:65, and 20:80 forage-to-concentrate ratio, respectively.

a transient peak but remained greater throughout the feeding cycle when low $\mathrm{F}: \mathrm{C}$ diets were fed.

The initial rate of $\mathrm{pH}$ drop, the initial rate of VFA increase, and the VFA range were not affected by F:C. Decreasing F:C linearly increased the molar proportion of propionate and decreased the molar proportion of acetate $(P<0.001)$, as well as the acetate-to-propionate ratio and the molar proportion of caproate. Decreasing F:C also linearly decreased the molar proportion of isobutyrate and tended to decrease the molar proportion of isovalerate, whereas ammonia concentration linearly increased $(P<0.001)$. The molar proportion of butyrate remained unaffected.

Feeding $\mathrm{R}$ diets decreased the mean ruminal $\mathrm{pH}(P$ $<0.005)$ and minimum $\mathrm{pH}(P<0.001)$. It increased the initial rate of $\mathrm{pH}$ drop, the $\mathrm{pH}$ range, the time during which the $\mathrm{pH}$ was below 6.0 and $5.8(P<0.01)$, and the area under the curve of $\mathrm{pH} 6.0$ and $5.8(P<$ 0.001). Feeding $\mathrm{R}$ diets sharply increased the range of VFA $(+24 \mathrm{~m} M, P<0.001)$ and the initial rate of VFA increase, whereas mean VFA concentration was only marginally increased $(P<0.10)$ and lactate concentration was unaffected $(P>0.10)$. Increasing CRDM also increased the molar proportion of propionate and decreased the molar proportion of acetate and the acetateto-propionate ratio $(P<0.001)$. It also increased the molar proportion of valerate and decreased the molar proportion of butyrate and caproate $(P<0.001)$. The molar proportions of isobutyrate and isovalerate were not affected $(P>0.10)$, and ammonia concentration was decreased $(P<0.001)$.

\section{Liquid Passage Rate and Fibrolytic Activity}

The effects of F:C and CRDM on dynamics of ruminal liquids and ruminal fibrolytic activity are presented in Table 7. Decreasing F:C decreased the fractional outflow rate when $\mathrm{S}$ diets were fed but not when $\mathrm{R}$ diets were fed (interaction F:C $\times \mathrm{CRDM}, P=0.01$ ). Decreasing F:C linearly reduced ruminal liquid volume $(P<0.05)$, daily ruminal liquid outflow $(\mathrm{L} / \mathrm{d})$, and ruminal liquid flow per kilogram of DMI $(P<0.001)$. Rumen dynamics of liquids were not affected by CRDM apart from liquid outflow per kilogram of DMI, which was marginally greater when $\mathrm{R}$ diets were fed. The in sacco disappearance of soybean hulls DM was unaffected by $\mathrm{F}$ :C but was reduced when feeding $\mathrm{R}$ diets.

\section{Digestibility}

Digestibility data are presented in Table 8. Decreasing $\mathrm{F}: \mathrm{C}$ decreased $\mathrm{OM}$ and $\mathrm{CP}$ digestibility but only when $\mathrm{R}$ diets were fed (interaction $\mathrm{F}: \mathrm{C} \times \mathrm{CRDM}, P<$ $0.05)$. It also decreased ADF digestibility. Neutral detergent fiber digestibility peaked when $\mathrm{F}$ : $\mathrm{C}$ was 35:65. When feeding $\mathrm{R}$ diets, $\mathrm{OM}$ and $\mathrm{CP}$ digestibility were increased, whereas ADF digestibility was decreased. Digestibility of NDF was not affected. Starch digest-

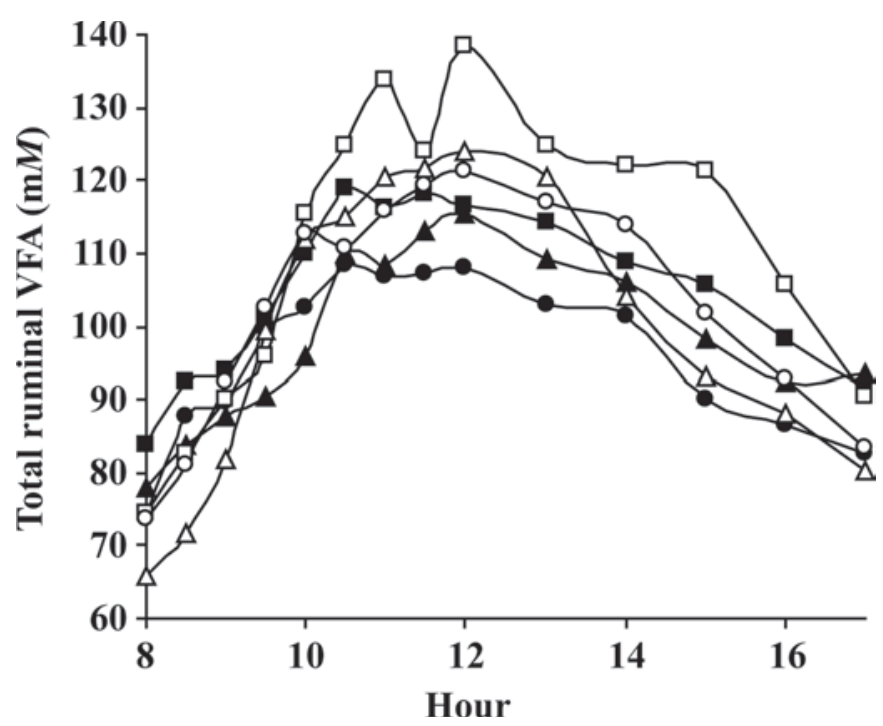

Figure 2. Postfeeding fluctuations in total ruminal VFA for diets differing in forage-to-concentrate ratio and rapidly degradable DM from concentrate. S50: - ; S35: $\mathbf{\Delta}$; S20: $\mathbf{\square}$; R50: O; R35: $\Delta$; R20: $\square$. S50, S35, S20 = slowly degradable concentrate combined with 50:50, 35:65, and 20:80 forage-to-concentrate ratio, respectively; R50, R35, $\mathrm{R} 20$ = rapidly degradable concentrate combined with 50:50, 35:65, and 20:80 forage-to-concentrate ratio, respectively. 
Table 7. Effects of forage-to-concentrate ratio (F:C) and dietary content of rapidly degradable DM from concentrate (CRDM) on fractional outflow rate of liquid (FORL), liquid volume, and liquid outflow of the rumen

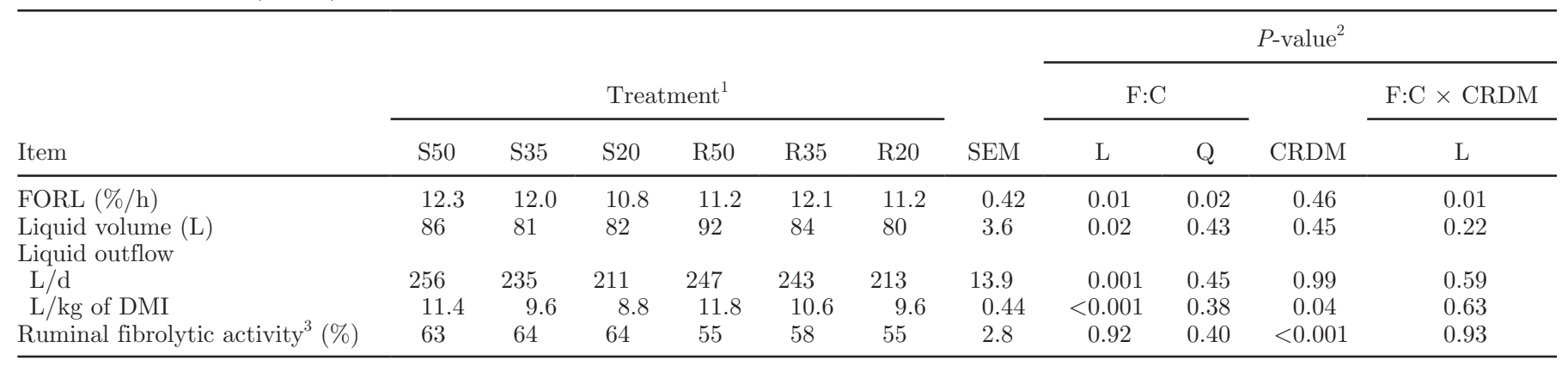

${ }^{1}$ Treatments: S50, S35, S20 = slowly degradable concentrate combined with 50:50, 35:65, and 20:80 forage-to-concentrate ratio, respectively; R50, R35, R20 = rapidly degradable concentrate combined with 50:50, 35:65, and 20:80 forage-to-concentrate ratio, respectively.

${ }^{2} \mathrm{~L}=$ linear; $\mathrm{Q}=$ quadratic.

${ }^{3}$ Disappearance rate of soybean hulls DM incubated in nylon bags for $24 \mathrm{~h}$.

ibility increased $(P<0.001)$, but this increase was greater when feeding a high $\mathrm{F}: \mathrm{C}$ diet (interaction, $\mathrm{F}: \mathrm{C}$ $\times$ CRDM,$P<0.05)$.

\section{Milk, Protein, and Fat Yield}

Data on milk production and composition are presented in Table 9. Decreasing F:C linearly increased milk yield, protein yield, and milk protein content; decreased milk fat content; and tended to decrease milk fat yield. Feeding $\mathrm{R}$ diets did not affect milk yield, protein yield, or milk protein content but reduced milk fat yield and milk fat content $(P<0.05)$.

Decreasing F:C did not affect the yield of even shortchain fatty acids (C4:0 to C12:0) or the yield of monounsaturated fatty acids. It linearly increased the yield of polyunsaturated fatty acids, $\mathrm{C} 18: 2$, and trans-10 C18:1 $(P<0.005)$; linearly decreased the yield of cis-9 C18:1; and tended to decrease the yields of C16 and C18. The yield of all saturated odd-chain fatty acids (C5:0 to C17:0) peaked when F:C was 35:65. Feeding R diets increased the yield of all saturated odd-chain fatty acids and decreased the yield of even short-chain fatty acids, as well as the yield of C14:0, C16:0, and C18:0. Feeding $\mathrm{R}$ diets moderately increased the yield of trans-10 C18:1 and reduced the yield of trans-11 C18:1. The yield of cis-9,trans-11 C18:2 was not affected by the treatments.

\section{DISCUSSION}

\section{Fibrousness of the Diets}

It is generally agreed that SARA occurs in repeated periods of depressed pH below 5.6 to 5.8 (Beauchemin et al., 2003; Rustomo et al., 2006a; Yang and Beauchemin, 2009). According to these threshold values, SARA oc- curred in cows on the R20, R35, R50, and S20 diets (Figure 1). The very low fat levels observed in all diets $(26.2 \mathrm{~g} / \mathrm{kg})$ compared with the reference period $(37.9 \mathrm{~g} /$ $\mathrm{kg}$ ) also support that SARA occurred in cows fed these diets.

The supply of fiber in the diets used in this study was far below the recommended values. To avoid a $\mathrm{pH}$ drop below the threshold values triggering SARA, the NRC (2001) recommends a minimum of $25 \%$ dietary NDF and $19 \%$ FNDF. The FNDF content of the diets used in the current study hardly reached this threshold value for $\mathrm{F}$ :C of 50:50 and decreased to 13.2 and $7.6 \%$ when F:C was 35:65 and 20:80, respectively. The concept of peNDF was developed to characterize more precisely

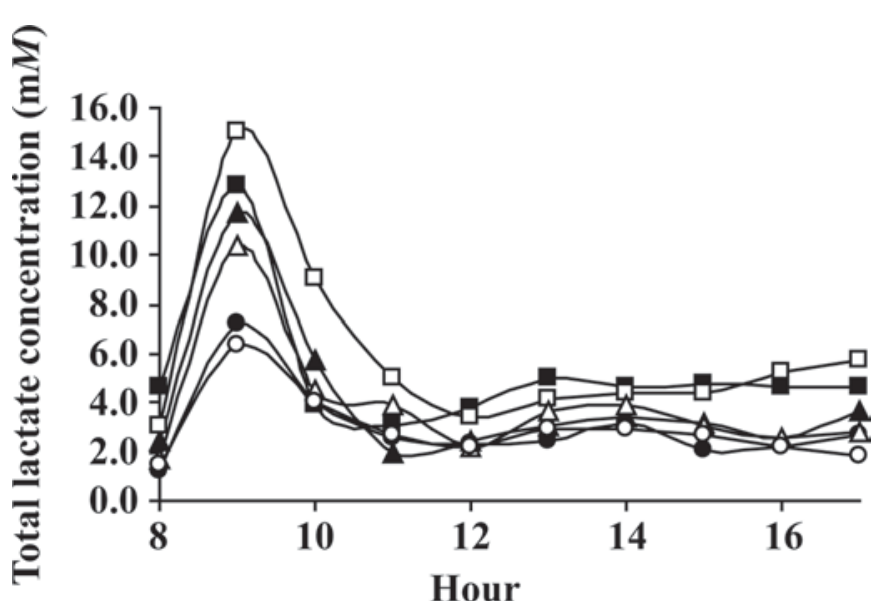

Figure 3. Postfeeding fluctuations in total ruminal lactate for diets differing in forage-to-concentrate ratio and rapidly degradable DM from concentrate. S50: O; S35: $\boldsymbol{\Delta}$; S20: $\boldsymbol{\square}$; R50: O; R35: $\Delta$; R20: $\square$. S50, S35, S20 = slowly degradable concentrate combined with 50:50, 35:65, and 20:80 forage-to-concentrate ratio, respectively; R50, R35, $\mathrm{R} 20$ = rapidly degradable concentrate combined with 50:50, 35:65, and 20:80 forage-to-concentrate ratio, respectively. 
Table 8. Effects of forage-to-concentrate ratio (F:C) and dietary content of rapidly degradable DM from concentrate (CRDM) on total-tract digestibility

\begin{tabular}{|c|c|c|c|c|c|c|c|c|c|c|c|}
\hline Total-tract digestibility (\%) & \multicolumn{6}{|c|}{ Treatment $^{1}$} & SEM & \multicolumn{4}{|c|}{$P$-value ${ }^{2}$} \\
\hline$\overline{\mathrm{OM}}$ & 71.9 & 71.3 & 70.7 & 75.3 & 73.6 & 70.8 & 0.66 & $<0.001$ & 0.65 & 0.001 & 0.02 \\
\hline NDF & 46.9 & 49.4 & 44.9 & 44.8 & 47.7 & 43.7 & 1.68 & 0.34 & 0.02 & 0.21 & 0.78 \\
\hline $\mathrm{ADF}$ & 47.8 & 47.9 & 43.0 & 44.5 & 41.4 & 38.3 & 1.68 & 0.003 & 0.38 & 0.002 & 0.67 \\
\hline
\end{tabular}

${ }^{1}$ Treatments: S50, S35, S20 = slowly degradable concentrate combined with 50:50, 35:65, and 20:80 forage-to-concentrate ratio, respectively; $\mathrm{R} 50, \mathrm{R} 35, \mathrm{R} 20$ = rapidly degradable concentrate combined with 50:50, 35:65, and 20:80 forage-to-concentrate ratio, respectively.

${ }^{2} \mathrm{~L}=$ linear; $\mathrm{Q}=$ quadratic.

the physical effectiveness of diets. A minimum of $22 \%$ of dietary peNDF 1.18 is required to maintain the mean daily $\mathrm{pH}$ at 6.0 for all diets whatever the nature of the concentrate (Mertens, 1997). Again, the values of the diets used in this study were far below this threshold value (from 7 to $18 \%$, Table 3 ). The response curve produced by Mertens (1997) clearly shows a very rapid decrease of ruminal $\mathrm{pH}$ when peNDF $\mathrm{N}_{1.18}$ drops from 20 to $10 \%\left(-0.05 \mathrm{pH}\right.$ unit $\left./ 1 \% \mathrm{peNDF}_{1.18}\right)$.

These criteria regarding fiber do not account for differences in ruminal fermentability of concentrates, which can have a major effect on ruminal $\mathrm{pH}$ (Krause et al., 2002; Rustomo et al., 2006a; Plaizier et al., 2008).
The use of feedstuffs with a high rate of fermentation in $\mathrm{R}$ diets might contribute to enhancing the effects of the low peNDF content on ruminal fermentation. Very few interactions between F:C and CRDM were detected, thus indicating that the effects of the 2 factors are mostly additive. Krause et al. (2002) reported that the effects on ruminal $\mathrm{pH}$ of increasing the dietary content of rapidly degradable starch in the rumen do not depend on the forage particle size and, thus, the supply of peNDF ${ }_{1.18}$.

Limiting the duration of access to the manger, coupled with the slight reduction in intake level, which increases the eating rate, was chosen to avoid the apparition of

Table 9. Effects of forage-to-concentrate ratio (F:C) and dietary content of rapidly degradable DM from concentrate (CRDM) on milk yield, milk composition, and milk fatty acids yields

\begin{tabular}{|c|c|c|c|c|c|c|c|c|c|c|c|}
\hline Item & \multicolumn{6}{|c|}{ Treatment $^{1}$} & SEM & \multicolumn{4}{|c|}{$P$-value ${ }^{2}$} \\
\hline Milk yield $(\mathrm{kg} / \mathrm{d})$ & 37.9 & 36.8 & 39.0 & 36.0 & 36.8 & 38.6 & 2.79 & 0.03 & 0.13 & 0.26 & 0.38 \\
\hline Protein yield $(\mathrm{kg} / \mathrm{d})$ & 1.07 & 1.08 & 1.16 & 1.03 & 1.08 & 1.16 & 0.050 & $<0.001$ & 0.31 & 0.44 & 0.54 \\
\hline Protein content $(\mathrm{g} / \mathrm{kg})$ & 28.7 & 29.6 & 30.0 & 29.1 & 29.9 & 30.4 & 1.19 & 0.01 & 0.68 & 0.27 & 0.94 \\
\hline \multicolumn{12}{|c|}{ Milk fatty acids yields (g/d) } \\
\hline C5:0 to $\mathrm{C} 17: 00$ & 25.3 & 25.0 & 22.2 & 27.4 & 31.8 & 28.0 & 1.50 & 0.35 & 0.03 & $<0.001$ & 0.17 \\
\hline $\mathrm{C} 4: 0$ to $\mathrm{C} 12: 0$ & 174.1 & 176.1 & 153.5 & 130.8 & 137.6 & 127.1 & 17.43 & 0.32 & 0.33 & 0.002 & 0.49 \\
\hline $\mathrm{C} 14: 0$ & 114.6 & 113.8 & 100.4 & 85.4 & 88.7 & 80.1 & 8.90 & 0.15 & 0.29 & $<0.001$ & 0.50 \\
\hline C16:0 & 265.4 & 257.7 & 216.7 & 195.5 & 216.7 & 172.4 & 20.66 & 0.06 & 0.13 & 0.002 & 0.48 \\
\hline $\mathrm{C} 18: 0$ & 92.1 & 81.9 & 65.6 & 55.0 & 58.6 & 47.9 & 9.60 & 0.07 & 0.51 & 0.002 & 0.28 \\
\hline Monounsaturated & 261.5 & 235.4 & 221.2 & 214.5 & 229.4 & 201.6 & 21.95 & 0.20 & 0.66 & 0.15 & 0.50 \\
\hline $\mathrm{C} 18: 2$ & 27.6 & 29.9 & 33.6 & 21.5 & 24.3 & 27.5 & 2.16 & 0.004 & 0.79 & 0.001 & 0.99 \\
\hline cis-9,trans-11 C18:2 & 3.7 & 3.6 & 1.8 & 2.2 & 3.0 & 3.2 & 0.93 & 0.59 & 0.48 & 0.76 & 0.10 \\
\hline
\end{tabular}

${ }^{1}$ Treatments: S50, S35, S20 = slowly degradable concentrate combined with 50:50, 35:65, and 20:80 forage-to-concentrate ratio, respectively; R50, R35, R20 = rapidly degradable concentrate combined with 50:50, 35:65, and 20:80 forage-to-concentrate ratio, respectively.

${ }^{2} \mathrm{~L}=$ linear; $\mathrm{Q}=$ quadratic. 
small meals and to better characterize the ruminal effect of the TMR (Le Liboux and Peyraud, 1999).

\section{Effects of F:C}

Decreasing F:C increased DMI because the substitution between concentrate and forages is generally less than 1.0 irrespective of the carbohydrate source of the concentrate (Faverdin et al., 1987). The substitution between corn silage and concentrate averaged 0.55 when F:C decreased from 50:50 to 35:65. The effect of replacing forage with concentrate on DMI $(+1.7 \mathrm{~kg} / \mathrm{d})$ is within the range predicted by the French Fill Units $(+1.4 \mathrm{~kg} / \mathrm{d}$; INRA, 1989). Dry matter intake response was not affected when F:C further decreased to 20:80 and the marginal substitution rate increased up to 1.04, thus suggesting that some physiological limits were reached. The cows might have adjusted intake in response to the increased molar proportion of propionate when F:C decreased. Propionate could have reduced DMI by increasing insulin secretion, as proposed by Grovum (1995). Alternatively, cows might have adjusted intake in response to low ruminal $\mathrm{pH}$. Krause et al. (2002) previously reported the relationship between the extent of ruminal $\mathrm{pH}$ depression below 5.8 and the decrease in DMI. Beauchemin and Yang (2005) also reported that reducing the supply of peNDF did not increase DMI in diets with F:C averaging 40:60.

Decreasing F:C linearly decreased the average time spent chewing per kilogram of DMI, with $83 \%$ of this effect being explained by a reduction in ruminating time. The decrease in physical effectiveness of the diet through decreasing the dietary content of long particles is certainly the main factor explaining the decrease in the chewing time (Mertens, 1997). Beauchemin and Yang (2005) have suggested that chewing activity is not affected when peNDF $_{8.0}$ is greater than $10 \%$ but steadily decreases when peNDF ${ }_{8.0}$ is below $10 \%$. Dietary peNDF ${ }_{8.0}$ was below this threshold value for the 35:65 and 20:80 diets. The increase in DMI might have also contributed to the reduction in the average time spent chewing per kilogram of DMI. According to Sauvant et al. (1990), the chewing time per kilogram of DMI decreases by $2.4 \mathrm{~min} / \mathrm{d}$ when DMI increases by 1 $\mathrm{kg} / \mathrm{d}$. The decrease in eating time confirms the findings reported by Yang and Beauchemin (2007). It can be explained by the faster intake rate of pelleted concentrate in comparison with coarse forage (Beauchemin et al., 2008).

Decreasing F:C reduced mean $\mathrm{pH}$, increased $\mathrm{pH}$ range and the time during which $\mathrm{pH}$ was below 6.0 and 5.8, and decreased the acetate-to-propionate ratio. These effects conform well to data previously reported in studies on SARA (Yang and Beauchemin, 2007; Yang and Beauchemin, 2009). The linear increase of the yield of trans-10 C18:1 in milk as F:C decreased also suggests a shift in the biohydrogenation pathways of $\mathrm{C} 18: 2$ that became oriented to trans-10 C18:1 instead of trans-11 C18:1 (Bauman and Griinari, 2003). Decreasing F:C is generally associated with an increased proportion of grain, and traditionally, such results were related to a greater production of VFA in the rumen (Plaizier et al., 2008) because grains are more rapidly degraded in the rumen than are forages. In our study, the NDF content of the diets and the supply of CRDM were kept as constant as possible; thus, the variation of $\mathrm{F}$ : $\mathrm{C}$ was chiefly related to variation of peNDF content in the diet. In this case, decreasing F:C linearly decreased digestibility, but the range of the VFA increase during the meal was not affected, thus indicating that the dynamics of $\mathrm{pH}$ were not related to the VFA concentration. Conversely, the effects on the dynamics of $\mathrm{pH}$ would be related to a decrease in acid removal from the rumen. The sharp decrease in the average time spent chewing per kilogram of DMI would have led to a decrease in salivary flow and finally a decrease in ruminal buffering capacity. This hypothesis is also supported by the decrease in ruminal liquid flow. Jacques et al. (1989) have shown that variations of liquid flow are closely correlated to variations of the salivary flow.

Reducing $\mathrm{F}$ : $\mathrm{C}$ linearly decreased ADF digestibility and decreased NDF digestibility between the medium and the low F:C. This result is partly related to the choice of feedstuffs. To keep a constant CRDM, the proportion of straw, wheat bran, and soybean hulls, which are less digestible than grain or citrus pulp (INRA-AFZ, 2004), was increased resulting in a decrease in concentrate digestibility (i.e., 87.8, 83.6, 82.0\%, respectively, for diets 50:50, 35:65, and 20:80). Citrus pulp was introduced into the S50 and R50 diets, and the pectins, which are highly digestible, were not taken into account in the determination of NDF as shown by the difference between NDF $(19.3 \%)$ and water insoluble cell walls $(33.1 \%$; INRA-AFZ, 2004). This suggests that the digestibility of the whole insoluble cell-wall fraction was underestimated for these 2 diets when measured as NDF, thus explaining the more erratic effect of decreasing $\mathrm{F}$ : $\mathrm{C}$ on NDF digestibility than on ADF digestibility

Reducing F:C did not modify the fibrolytic activity of the rumen estimated from the disappearance of soybean hulls DM after $24 \mathrm{~h}$ of in sacco incubation in the rumen. This contrasts with our previous results in which dietary peNDF was decreased by grinding the forage (Le Liboux and Peyraud, 1999). It is recognized that the growth of cellulolytic bacteria is impaired for $\mathrm{pH}$ below 6.0 to 5.8 (Hoover, 1986). Decreasing F:C from 50:50 to 20:80 increased periods during which the $\mathrm{pH}$ was below 5.8 from 1.1 to $3.6 \mathrm{~h}$. This suggests that 
the ranges of variation of these criteria were not sufficient for producing negative effects on the growth of cellulolytic bacteria.

\section{Effects of the Dietary Content of Rapidly Degradable Carbohydrates}

Increasing the dietary content of rapidly degradable carbohydrates sharply decreased DMI $(-2.1 \mathrm{~kg} / \mathrm{d})$. Decreased DMI has been previously reported when increasing the dietary content of rapidly degradable starch by replacing corn with barley without modifying the dietary starch content (Overton et al., 1995). Krause et al. (2002) also reported a significant reduction in DMI when increasing the dietary content of rapidly degradable carbohydrates by replacing dry corn with high-moisture corn. The increase in the molar proportion of propionate when increasing CRDM could partly explain this result, as previously discussed. Moreover, increasing CRDM has increased VFA range, which, in turn, might have increased ruminal osmolality with a possible feedback effect on DMI because salt infusion studies (Bergen, 1972) have shown that rumen osmolality is a major regulatory factor of intake. The increase of the flow of liquid per kilogram of DMI when increasing CRDM would be consistent with an increase of osmolaliy in the rumen (López et al., 1994).

Increasing the dietary content of rapidly degradable carbohydrates decreased the mean $\mathrm{pH}$ and increased the $\mathrm{pH}$ range, the initial rate of $\mathrm{pH}$ drop, and the time below $\mathrm{pH} 6.0$ and 5.8. Many authors have shown a decrease in mean ruminal $\mathrm{pH}$ when replacing slowly degradable starch (i.e., dry corn, sorghum) with rapidly degradable starch (i.e., high-moisture corn, barley, wheat) (Overton et al., 1995; Krause et al., 2002) in a diet rich in concentrates. In contrast, ruminal fermentation seems insensitive to the variations of the rate of starch degradation in forage-rich diets (Sauvant, 1997). In the current study, the dietary content of rapidly degradable carbohydrates was increased by modifying the sources of fiber and starch at a constant starch-to-NDF ratio. These findings suggest that the $\mathrm{pH}$ dynamic is affected by the amount of rapidly degradable carbohydrates and that some feedstuffs rich in rapidly degradable insoluble cell walls are acidogenic. Using an in vitro technique, De Smet et al. (1995) and Rustomo et al. (2006b) have determined the acidogenicity of several feedstuffs and have shown that feedstuffs rich in pectins, such as beet pulp, are even more acidogenic than rapidly fermented starches. De Smet et al. (1995) showed that the ability of feedstuffs to decrease ruminal $\mathrm{pH}$ in a relatively short period of time (i.e., from 1 to $5 \mathrm{~h}$ after the beginning of in vitro incubation) can be predicted from the in sacco disappearance of DM after $3 \mathrm{~h}$ of incubation irrespective of the nature of the feedstuff. Feeding $\mathrm{R}$ diets increased the yield of trans-10 C18:1 and reduced the yield of trans-11 C18:1 in milk. These findings suggest that increasing the amount of rapidly degradable carbohydrates induces a microbial change resulting in a profound modification of ruminal biohydrogenation and isomerization of C18:2.

Increasing the dietary content of rapidly degradable carbohydrates accelerated the initial rate of increase of VFA concentration and increased the range of VFA after the meal. Kung et al. (1992) also reported an increase in the VFA range when replacing corn with barley in steers' diets. $\mathrm{R}$ diets also led to a lower $\mathrm{pH}$, which is known to increase the rate of VFA absorption (Allen, 1997), and did not affect rumen volume, thus suggesting that postprandial variations of VFA concentration reflect variations of VFA production. This suggests that feeding $\mathrm{R}$ diets largely increased the rate of acid production conversely to the decrease of $\mathrm{F}$ :C. Indeed, the initial rate of $\mathrm{pH}$ drop and the range of $\mathrm{pH}$ are, respectively, well correlated to the initial rate of increase of VFA concentration $(\mathrm{r}=0.92, \mathrm{n}=6)$ and the range of VFA $(\mathrm{r}=0.89, \mathrm{n}=6)$ for the 6 diets. The limited effects of $\mathrm{R}$ diets on chewing activity and on the liquid passage rate suggest that regulation of saliva secretion did not play a major role in the regulation of the dynamics of $\mathrm{pH}$ when increasing the supply of rapidly degradable carbohydrates.

Increasing the dietary content of rapidly degradable carbohydrates sharply decreased the acetate-topropionate ratio, which agrees with many studies in which slowly degradable starch was replaced with rapidly degradable starch (Overton et al., 1995; Krause et al., 2002). This finding can be related to the change in ruminal pH. Calsamiglia et al. (2008) showed from an in vitro study that the production of acetate is decreased at a low $\mathrm{pH}$ because of a reduction in activity of fibrolytic bacteria (Hoover, 1986), which are acetate producers. Conversely, the production of propionate is increased (Calsamiglia et al., 2008) because of the ability of starch-degrading bacteria, which preferentially produce propionate, to adapt to a low $\mathrm{pH}$ (Russell, 1998).

Increasing the dietary content of rapidly degradable carbohydrates reduced fibrolytic activity, which was not the case when decreasing $\mathrm{F}: \mathrm{C}$, although the 2 factors affected the dynamics of ruminal $\mathrm{pH}$. However, a longer time below $\mathrm{pH} 5.8$ was obtained with $\mathrm{R}$ diets, and the range of $\mathrm{pH}$ variation was more affected when increasing the content of rapidly degradable carbohydrates than when decreasing F:C (+0.43 vs. $+0.31 \mathrm{pH}$ unit, respectively), the range of $\mathrm{pH}$ variation being greater than one $\mathrm{pH}$ unit for all $\mathrm{R}$ diets. Therefore, it can be hypothesized that increasing the content of rapidly 
Table 10. Regression models predicting ruminal fermentation parameters with dietary content of NDF from forage (FNDF; $\mathrm{g} / \mathrm{kg}$ of DM) and dietary rapidly degradable DM from concentrate (CRDM; g/kg of DM) $(\mathrm{n}=6)$

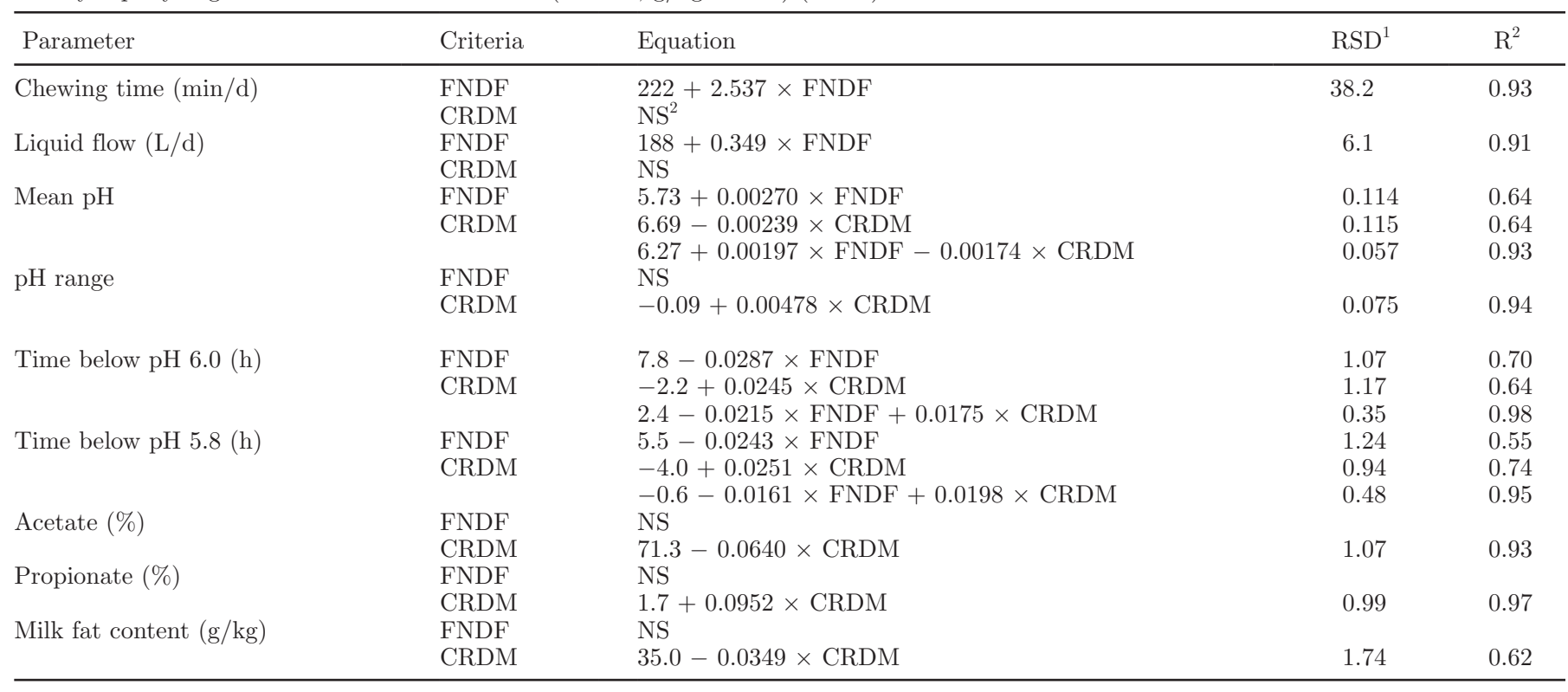

${ }^{1}$ Residual SD.

${ }^{2} \mathrm{NS}=$ nonsignificant.

degradable carbohydrates allowed us to reach sufficient ruminal $\mathrm{pH}$ disturbance to impair growth of cellulolytic bacteria, whereas decreasing F:C did not. This finding also means that fibrolytic activity would be more sensitive to the total range of variations of $\mathrm{pH}$ rather than mean $\mathrm{pH}$ or time spent below $\mathrm{pH} 5.8$.

\section{Prediction of Ruminal $\mathrm{pH}$ and VFA Profile}

The mean ruminal $\mathrm{pH}$ was strongly correlated with FNDF (Table 10) and not with total NDF, indicating the importance of FNDF in maintaining ruminal $\mathrm{pH}$ in a physiological range. In a meta-analysis, Zebeli et al. (2008) also found greater accuracy of predicting mean ruminal $\mathrm{pH}$ using criteria to characterize FNDF than total dietary NDF. In the current experiment, peNDF $_{8.0}$, peNDF $_{1.18}, \mathrm{FNDF}_{4}, \mathrm{FNDF}_{2}$, and FNDF were closely linked and decreased proportionally to $\mathrm{F}$ : $\mathrm{C}$. It is not possible to determine the more appropriate criteria. However, Yang and Beauchemin (2009) suggested that the precision of ruminal $\mathrm{pH}$ prediction increased as more particle fractions were included in the calculation. Therefore, FNDF seems to be a relevant criterion and is easily available. The positive effect of FNDF on mean ruminal $\mathrm{pH}$ and time below $\mathrm{pH} 6.0$ or 5.8 is the result of the stimulation of chewing and saliva production. Total chewing time (in min/d) and liquid flow out of the rumen (in L/d) were highly correlated among the 6 diets to FNDF (chewing time, $\mathrm{r}=0.96$; liquid flow, $\mathrm{r}=0.95)$.
However, FNDF is not sufficient to formulate diets to prevent SARA. The correlations between FNDF and the range of $\mathrm{pH}(\mathrm{r}=0.50, P>0.10)$, the time below $\mathrm{pH}$ $5.8(\mathrm{r}=0.74, P<0.10)$, and the correlation between FNDF and milk fat content $(\mathrm{r}=0.64, P>0.10)$ were not great, suggesting that the rate of acid production should also be taken into account to formulate diets to prevent SARA. We have hypothesized that CRDM, estimated from disappearance of DM of concentrate after $4 \mathrm{~h}$ of in sacco incubation (Peyraud, 2000), could be an indicator of the fermentability of carbohydrates from the concentrate. The correlations between CRDM and the range of the $\mathrm{pH}$ fall during the meal $(\mathrm{r}=0.97$, $P<0.01)$, the time below $\mathrm{pH} 5.8(\mathrm{r}=0.86, P<0.05)$, and the milk fat content $(\mathrm{r}=0.79, P<0.10)$ were greater than the correlations between FNDF and these last parameters (Table 10). Using another indicator of the acidogenic value of concentrate, Rustomo et al. (2006a) also concluded that fermentative characteristics of concentrate are better predictors of the time below $\mathrm{pH} 5.8$ than is FNDF. Acetate and propionate molar proportions were also highly correlated with CRDM. This finding suggests that the VFA profile is dependent on the amount of available energy for rumen microbes, as previously stated by Sauvant and Van Milgen (1995). In contrast, CRDM was not correlated with chewing time and liquid flow. It could be concluded that both FNDF, which regulates salivary flow, and CRDM, which regulates the dynamics of fermentation, are both required to predict the risk of SARA. This is further 
illustrated by the fact that using FNDF and CRDM together improves the prediction of the mean ruminal $\mathrm{pH}$ and the time spent below $\mathrm{pH} 6.0$ or 5.8 :

$$
\begin{gathered}
\text { Time below pH } 5.8(\mathrm{~h})=-0.6-0.0161 \\
\quad \times \text { FNDF }+0.0198 \times \mathrm{CRDM} \\
\left(\mathrm{n}=6 ; \text { residual } \mathrm{SD}=0.48 ; \mathrm{r}^{2}=0.95\right)
\end{gathered}
$$

\section{CONCLUSIONS}

The dietary content of physically effective fiber and rapidly degradable carbohydrates had major effects on ruminal $\mathrm{pH}$, but the mechanisms of regulation were different. Decreasing the dietary content of physically effective fiber decreased acid removal from the rumen, and this was primarily mediated through a reduction of the average time spent chewing per kilogram of DMI and regulation of saliva flow without having a significant effect on acid production. Increasing dietary content of rapidly degradable carbohydrates increased the rate of acid production without having an effect on saliva flow. Consequently, the content of NDF from the forage is a good predictor of chewing time, mean ruminal $\mathrm{pH}$, and time below $\mathrm{pH}$ 5.8, whereas rapidly degradable carbohydrates (calculated as DM that disappeared after $4 \mathrm{~h}$ of in sacco incubation) is a good predictor of the range of $\mathrm{pH}$ variation and acetate and propionate molar proportions. These results clearly show that both NDF from forage and the fermentative characteristics of the concentrate should be taken into account when formulating diets to prevent SARA.

\section{ACKNOWLEDGMENTS}

This study was financially supported by Conseils et Compétences en Productions Animales (CCPA, Janzé, France) and Techna (Couëron, France). We particularly thank Rémy Chérel (CCPA) and Emmanuel David (Techna) for enriching discussions on this trial. We are also grateful to Philippe Lamberton and the farm staff for cow welfare, feeding, and sampling. The authors also thank Thibaud Le Mouel, Laurence Finot, and Nicole Huchet for technical assistance and CARACTERE (Rennes, France) for correction of the English version of the manuscript.

\section{REFERENCES}

Allen, M. S. 1997. Relationship between fermentation acid production in the rumen and the requirement for physically effective fiber. J. Dairy Sci. 80:1447-1462.

Apper-Bossard, E., J. L. Peyraud, P. Faverdin, and F. Meschy. 2006. Changing dietary cation-anion difference for dairy cows fed with two contrasting levels of concentrate in diets. J. Dairy Sci. 89:749-760.
Association Française de Normalisation. 1985. Dosage de l'amidon. Méthode polarimétrique. Pages 123-125 Aliments des Animaux. Association Française de Normalisation, Paris, France.

Bauman, E., and J. Griinari. 2003. Nutritional regulation of milk fat synthesis. Annu. Rev. Nutr. 23:203-227.

Beauchemin, K. A., L. Eriksen, P. Norgaard, and L. M. Rode. 2008. Short communication: Salivary secretion during meals in lactating dairy cattle. J. Dairy Sci. 91:2077-2081.

Beauchemin, K. A., and W. Z. Yang. 2005. Effects of physically effective fiber on intake, chewing activity, and ruminal acidosis for dairy cows fed diets based on corn silage. J. Dairy Sci. 88:21172129

Beauchemin, K. A., W. Z. Yang, and L. M. Rode. 2003. Effects of particle size of alfalfa based dairy cow diets on chewing activity, ruminal fermentation, and milk production. J. Dairy Sci. 86:630643.

Bergen, W. G. 1972. Rumen osmolality as a factor in feed intake control of sheep. J. Anim. Sci. 34:1054-1060.

Brun, J. P., S. Prache, and G. Bechet. 1984. A portable device for eating behavior studies. Pages 1-8 in 5th Meeting of European Grazing Workshop. R. Armstrong and J. Doney, ed. Hill Farming Research Organisation, Midlothian, UK.

Calsamiglia, S., P. W. Cardozo, A. Ferret, and A. Bach. 2008. Changes in rumen microbial fermentation are due to a combined effect of type of diet and pH. J. Anim. Sci. 86:702-711.

De Smet, A. M., J. L. de Boever, D. L. de Brabander, J. M. Vanacker, and C. V. Boucqué. 1995. Investigation of dry matter degradation and acidotic effect of some feedstuffs by means of in sacco and in vitro incubations. Anim. Feed Sci. Technol. 51:297-315.

Faverdin, P., A. Hoden, and J. B. Coulon. 1987. Recommandations alimentaires pour les vaches laitières. Bullet. Tech. CRZV Theix INRA 70:133-152.

Gill, J. L. 1978. Completely randomized designs of analysis of variance. Page 135-258 in Design and Analysis of Experiments in the Animal and Medical Sciences. Vol. 1. J. L. Gill, ed. Iowa State Univ. Press, Ames.

Grant, R. J., V. F. Colenbrander, and D. R. Mertens. 1990. Milk depression in dairy cows: Role of silage particle size. J. Dairy Sci. 73:1834-1842.

Grovum, W. L. 1995. Mechanisms explaining the effects of short chain fatty acids on feed intake in ruminants-osmotic pressure, insulin and glucagon. Pages 173-197 in Ruminant Physiology: Digestion, Metabolism, Growth and Reproduction. W. V. Englehardt, S. Leonhard-Marek, G. Breves, and D. Geisecke, ed. Ferdinand Enken Verlag, Stuttgart, Germany.

Hoover, W. H. 1986. Chemical factors involved in ruminal fiber digestion. J. Dairy Sci. 69:2755-2766.

Hurtaud, C., H. Rulquin, and R. Vérité. 1993. Effect of infused volatile fatty acids and caseinate on milk composition and coagulation in dairy cows. J. Dairy Sci. 76:3011-3020.

INRA. 1989. Ruminant Nutrition: Recommended Allowances and Feed Tables. R. Jarrige, ed. John Libbey, Eurotext, London, UK.

INRA-AFZ. 2004. Tables of Composition and Nutritional Value of Feed Materials. 2nd rev. and corrected ed. D. Sauvant, J. M. Perez, and G. Tran, ed. INRA, Paris, France.

Jacques, K., D. L. Harmon, W. J. Croom, and W. M. Hagler. 1989. Estimating salivary flow and ruminal water balance of intake, diet, feeding pattern, and slaframine. J. Dairy Sci. 72:443-452.

Kononoff, P. J., A. J. Heinrichs, and D. R. Buckmaster. 2003. Modification of the Penn State forage and total mixed ration Particle Separator and the effects of moisture content on its measurements. J. Dairy Sci. 86:1858-1863.

Krause, K. M., D. K. Combs, and K. A. Beauchemin. 2002. Effects of forage size and grain fermentability in midlactation cows. II. Ruminal pH and chewing activity. J. Dairy Sci. 85:1947-1957.

Kung, L. Jr., R. S. Tung, and B. R. Carmean. 1992. Rumen fermentation and nutrient digestion in cattle fed diets varying in forage and energy source. Anim. Feed Sci. Technol. 39:1-12.

Lammers, B. P., D. R. Buckmaster, and A. J. Heinrichs. 1996. A simple method for the analysis of particle sizes of forage and total mixed rations. J. Dairy Sci. 79:922-928. 
Le Liboux, S., and J. L. Peyraud. 1999. Effect of forage particle size and feeding frequency on fermentation patterns and sites and extent of digestion in dairy cows fed mixed diets. Anim. Feed Sci. Technol. 76:297-319.

López, S., F. D. Hovell, and N. A. MacLeod. 1994. Osmotic pressure, water kinetics and volatile fatty acid absorption in the rumen of sheep sustained by intragastric infusions. Br. J. Nutr. 71:153168 .

Mertens, D. R. 1997. Creating a system for meeting the fiber requirements of dairy cows. J. Dairy Sci. 80:1463-1481.

NRC. 2001. Nutrient Requirements of Dairy Cattle. 7th rev. ed. National Academy of Sciences, Washington, DC.

Overton, T. R., M. R. Cameron, J. P. Elliottt, J. H. Clark, and D. R. Nelson. 1995. Ruminal fermentation and passage of nutrients to the duodenum of lactating cows fed mixture of corn and barley. J. Dairy Sci. 78:1981-1998.

Peyraud, J. L. 2000. The fibrosity of the diet is partly determined by the rate of energy fermentation. Pages 183-186 in Proc. 7th Rencontres autour des Recherches sur les Ruminants, Paris, France. Institut de l'élevage, Paris, France.

Peyraud, J. L., L. Astigarraga, and P. Faverdin. 1997. Digestion of fresh perennial ryegrass fertilized at two levels of nitrogen by lactating dairy cows. Anim. Feed Sci. Technol. 64:155-171.

Plaizier, J. C., D. O. Krause, G. N. Gozho, and B. W. McBride. 2008. Subacute ruminal acidosis in dairy cows: The physiological causes, incidence and consequences. Vet. J. 176:21-31.

Russell, J. B. 1998. The importance of $\mathrm{pH}$ in the regulation of ruminal acetate to propionate ratio and methane production in vitro. J. Dairy Sci. 81:3222-3230.

Rustomo, B., O. AlZahal, N. E. Odongo, T. F. Duffield, and B. W. McBrode. 2006a. Effects of rumen acid load from feed and forage particle size on ruminal $\mathrm{pH}$ and dry matter intake in the lactating dairy cows. J. Dairy Sci. 89:4758-4768.

Rustomo, B., J. P. Cant, M. Z. Fan, T. F. Duffield, N. E. Odongo, and B. W. McBride. 2006b. Acidogenic value of feeds. I. The relationship between the acidogenic value of feeds and in vitro ruminal pH changes. Can. J. Anim. Sci. 86:109-117.

SAS Institute. 1999. SAS User's Guide: Statistics. Version 8.01. SAS Inst. Inc., Cary, NC.

Sauvant, D. 1997. Conséquences digestives et zootechniques des variations de la vitesse de digestion de l'amidon chez les ruminants. Prod. Anim. 10:287-300.

Sauvant, D., J. P. Dulphy, and B. Michalet-Doreau. 1990. Le concept d'indice de fibrosité des aliments des ruminants. Prod. Anim. 3:309-318.

Sauvant, D., and J. Van Miloen. 1995. Dynamic aspects of carbohydrate and protein breakdown and the associated microbial matter synthesis. Pages 71-91 in Ruminant Physiology: Digestion, Metabolism, Growth and Reproduction. Proc. 8th Int. Symp.on Ruminant Physiology. W. V. Engelhart, S. Leonard-Marek, G. Breves, D. Giesecke, ed., Delmar Publishers, Albany, Germany.

Tafaj, M., Q. Zebeli, Ch. Baes, H. Steingass, and W. Drochner. 2007. A meta-analysis examining effects of particle size of total mixed rations on intake, rumen, digestion and milk production in highyielding dairy cows in early lactation. Anim. Feed Sci. Technol. 138:137-161

Uden, P., P. E. Colucci, and P. J. Van Soest. 1980. Investigation of chromium, cerium and cobalt as markers in digesta. Rate of passage studies. J. Sci. Food Agric. 31:625-632.

Yang, W. Z., and K. A. Beauchemin. 2007. Altering physically effective fiber intake through forage proportion and particle length: Chewing and ruminal pH. J. Dairy Sci. 90:2826-2838.

Yang, W. Z., and K. A. Beauchemin. 2009. Increasing physically effective fiber content of dairy cow diets through forage proportion versus forage chop length: Chewing and ruminal pH. J. Dairy Sci. 92:1603-1615.

Zebeli, Q., J. Dijkstra, M. Tafaj, H. Steingass, B. N. Ametaj, and W. Drochner. 2008. Modeling the adequacy of dietary fiber in dairy cows based on the responses of ruminal $\mathrm{pH}$ and milk fat production to composition of the diet. J. Dairy Sci. 91:2046-2066. 